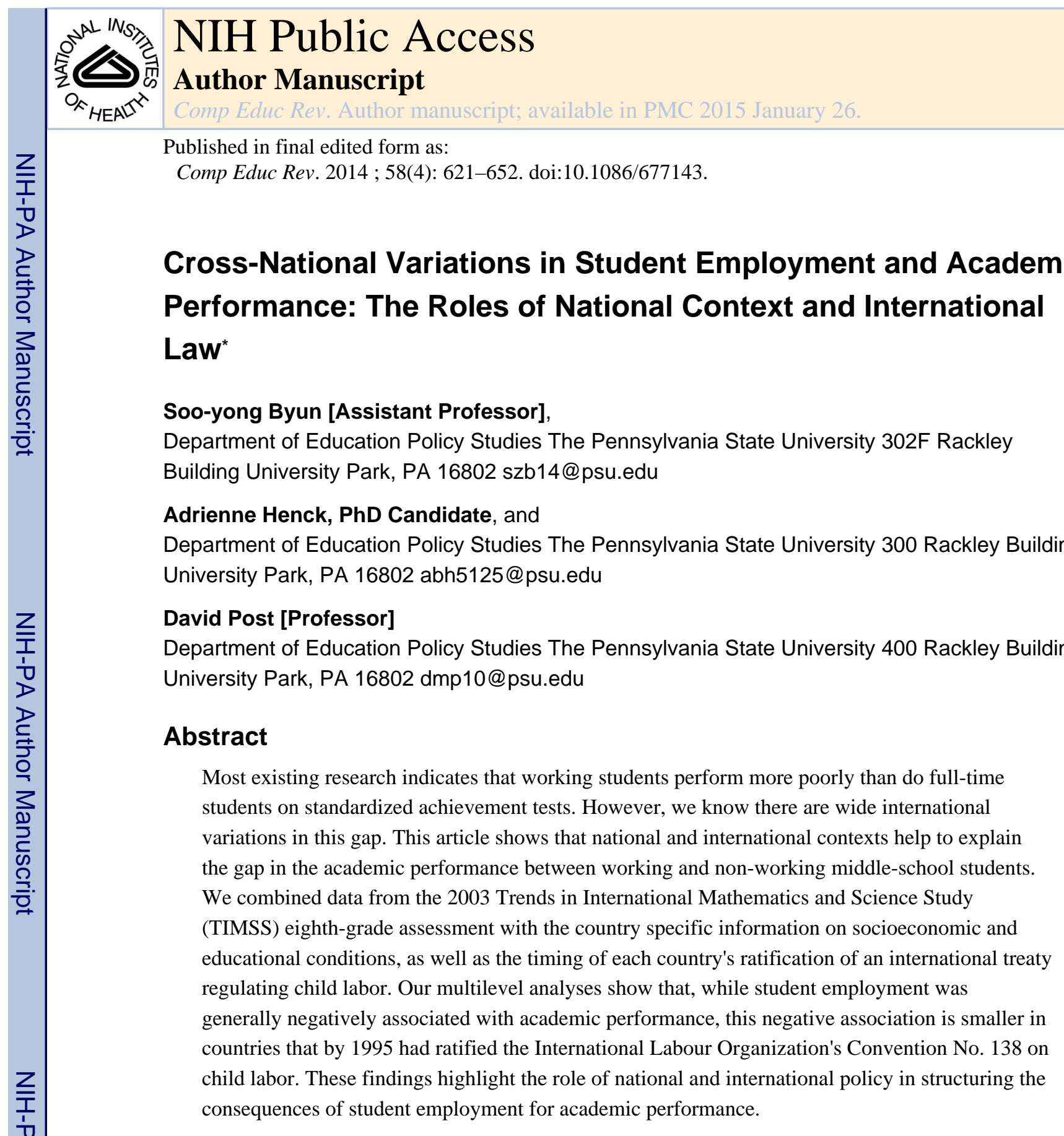

Governments, non-governmental organizations, and international agencies have sought to make schooling, rather than working, the major project of youth. The Education for All movement, led by the United Nations Educational, Scientific and Cultural Organization (UNESCO), has declared education to be a fundamental human right (UNESCO 2002). The International Labour Organization (ILO) has campaigned to reform legal codes to restrict and regulate employment during the years when schooling is compulsory. Partly as a result

\footnotetext{
*An earlier version of this manuscript was presented at the annual meeting of the Comparative and International Education Society (CIES), March 10-15, 2013, New Orleans, Louisiana. The authors thank Amita Chudgar and Evan Schofer for their helpful comments on an earlier draft.
}

Correspondence concerning this paper should be addressed to Soo-yong Byun, Department of Education Policy Studies, The Pennsylvania State University, 302F Rackley Building, University Park, PA 16802 (szb14@psu.edu). 
of such concerted efforts, the numbers of out-of-school children dramatically decreased. Merely since 1999, the numbers of primary school age children out of school fell from 108 million to 61 million (UNESCO 2012). However, these new populations of "students" are not necessarily full-time students. Many children maintain parallel economic activity, and so a substantial portion of students are now employed while attending school (Post 2011; Post and Pong 2000, 2009).

In many countries, students who combine work and schooling are likely to come from disadvantaged backgrounds. ${ }^{1}$ Researchers outside of the United States tend to find that working students perform worse in schools, compared to students who attend school only. ${ }^{2}$ However, some US researchers find ambiguous, threshold, or even moderately positive effects of some employment (Sabia 2009; Staff et al. 2010). It seems clear that the extent and impact of student employment varies cross-nationally (Pong and Pong 2000, 2009). Under what conditions, we must then ask, are students likely to combine paid employment with their school attendance? And, under what conditions is student employment most negatively associated with educational outcomes? Knowing the answers to these questions could help policy-makers craft reforms affecting children around the world. And, as yet, little research has investigated the roles of national or international policy contexts in shaping student employment and its consequences for academic performance. Instead, past research has been focused mainly on the determinants and effects of student employment at the individual level. ${ }^{3}$

In this article we build upon and extend past research by conceptualizing student employment—defined as paid employment outside school hours among school-age students -and its relationship with academic performance, as influenced by a multi-level process and mechanism. We examine whether national and international policy contexts shape both the prevalence and the impact of student employment. Here we draw on data from the 2003 Trends in International Mathematics and Science Study (TIMSS) eighth-grade assessment, combined with country-level data. These country-level data include several indicators of the national and international policy context that might explain cross-national differences in the prevalence and impact of student employment. To anticipate our findings: the data we use offer little evidence that national and international policy contexts are related to the likelihood of student employment, once controlling for student background characteristics.

At the same time, we find that, while student employment is generally negatively associated with academic performance, this negative association is smaller among students whose countries had ratified ILO Convention No. 138 on child labor by 1995, the year these children typically began their schooling. Thus, we find evidence that the national policy context matters for the consequence and the meaning of paid employment even if not for the propensity of paid employment.

\footnotetext{
${ }^{1}$ Lee and Staff 2007; Marsh and Kleitman 2005; Schoenhals, Tienda, and Schneider 1998; Staff and Mortimer 2005; Warren, LePore, and Mare 2000 .

${ }^{2}$ Gunnarsson, Orazem, and Sanchez 2006; Holgado et al. 2014; Marsh 1991; Marsh and Kleitman 2005; McCoy and Smyth 2007; Post and Pong 2000, 2009; Rothstein 2007; Singh, Chang, and Dika 2007.

3 D'Amico 1984; DeSimone 2006; Lillydahl 1990; Marsh 1991; Marsh and Kleitman 2005; McNeal 1997; Schoenhals et al. 1998; Singh 1998; Singh et al. 2007; Tyler 2003; Warren et al. 2000.
} 


\section{Theories and Research}

There are several theoretical perspectives on the decision-making by children and parents about paid employment and about the impact of such employment. These theoretical alternatives offer important insights into both the net impact and the mechanisms through which student employment affects the cognitive and non-cognitive development of children, but most of them focus on the determinants and effects of student employment at the individual level. An exception is Post and Pong's $(2000,2009,2011)$ framework which conceptualizes the effects of student employment within a national context. In this section, we first examine the three major theoretical perspectives, followed by Post and Pong's model, to understand cross-national differences in the prevalence of student employment and its impact on academic achievement.

\section{Zero-Sum Model}

One perspective is based on an economic theory of time allocation. Given their limited amounts of time and energy, children must divide their time between work and schooling. Time allocated towards work necessarily reduces the amount of time available for attending school, resting, and studying at home. This theoretical perspective, often labeled the "zerosum" model, predicts detrimental consequences for children's educational outcomes. Research based on the zero-sum model has focused on the impact of work intensity. Not only is intensive work associated with decreased school attendance and increased drop-out rates, but, from a human capital perspective, work also limits academic success by inhibiting the amount of cognitive skills children are able to acquire from schooling. ${ }^{4}$

There is a substantial body of evidence that supports the zero-sum model. ${ }^{5}$ For example, Ray and Lancaster (2005) analyzed the ILO's SIMPOC data on 12-14 year olds in seven countries (Belize, Cambodia, Namibia, Panama, the Philippines, Portugal, and Sri Lanka) and found that work, even in small amounts, adversely affects children's school attendance and performance (with the exception of Sri Lanka). Gunnarsson et al. (2006) examined the effect of work on the math and language test scores of third and fourth graders in nine Latin American countries and also found that in all countries working outside the home predicted lower academic performance regardless of labor intensity (measured by the amount of time spent at work). Finally, using nationally representative data for eighth-grade students in the United States (i.e., National Education Longitudinal Study of 1988 [NELS:88]), Marsh and Kleitman (2005) investigated the effects of working during high school on a set of academic and non-academic outcomes at four points in time: eighth, tenth, and twelfth grades, and two years after high school graduation. Their findings suggest that work generally has a negative effect on student outcomes regardless of characteristics such as ethnicity, gender, socioeconomic status, initial ability levels, and different types of work, lending support for the zero-sum model.

${ }^{4}$ Gunnarsson et al. 2006; Lee and Staff 2007; Marsh 1991; Marsh and Kleitman 2005; McNeal 1997; Ray and Lancaster 2005; Warren et al. 2000.

${ }^{5}$ Gunnarsson et al. 2006; Ray and Lancaster 2005; Singh et al. 2007; Zabaleta 2011. 


\section{Threshold Model}

In contrast with the zero-sum model, the threshold model suggests positive work effects up to a certain number of hours. Yet only limited evidence supports the empirical validity of this theoretical model. For example, Post and Pong (2000) conducted a longitudinal analysis on middle and high school students in the United States and a cross-sectional study of 22 other countries. In the United States, they found both that work in the eighth grade was detrimental to academic achievement, but also that low levels of work (less than ten hours per week) in tenth grade actually had a modest positive effect. However, they found that there was not a positive relationship between academic achievement and work (even at low levels) in any other countries in their analysis of 1995 TIMSS data.

Using data from NELS:88, Lee and Staff (2007) also tested threshold effects as well as reverse causality, i.e. the possibility that lower-achieving students are those who elect to work for pay. Lee and Staff used a propensity score matching technique to pair similar intensive workers with moderate workers in order to estimate the actual effect of work hours on the likelihood of high school completion. They found a negative effect of working 20 or more hours per week on the probability of dropping out. This finding supports the view that it is the act of working intensively, and not the background characteristics of students that affects educational outcomes. However, Lee and Staff (2007) and Staff et al. (2010) found that among students who have a high propensity for intensive work, working intensively is not associated with an increased likelihood of dropping out. Ultimately, the authors concluded that the variations in the effects of intensive work on different types of students further supports the idea that not all intensive work has negative consequences.

\section{Developmental/Socialization Model}

A third theoretical model highlights the effects of work on child development and socialization (Marsh 1991; Mortimer et al. 1992; Schoenhals et al. 1998). This perspective emphasizes that the habits and attitudes students learn from working have long-term effects extending beyond the actual period of work (Schoenhals et al. 1998). In addition to the often cited "character building" benefits, work can instill a sense of responsibility, independence, and strong work ethic that are crucial for children's successful transition to adulthood and that have important long-term labor market and stratification implications. These benefits may also indirectly impact academic achievement.

While this view predominates in the United States, parents in other cultural contexts also attribute positive effects to early work, particularly if the type of work fosters the development of cognitive skills such as numeracy and literacy and psycho-social skills such as developing a sense of self, forming social networks, and strengthening interpersonal relationships. For example, in a study of Senegal, Dumas (2012) found a positive effect on oral math scores. She attributed those skills to non-formal learning through trade (i.e., selling home-produced goods in the market) or service (e.g. collecting payment from customers on buses) occupations. Yet, due to instrument limitations, she did not find an effect of work on overall cognitive achievement. In contrast, using the High School and Beyond survey, a nationally representative data set of American high schoolers, Marsh (1991) found that work generally had a negative effect on a variety of academic and 
developmental outcomes, including self-concept, locus of control, aspirations, and getting into trouble. While these findings support the zero-sum model, there was also limited support for the developmental model in that students who worked in order to save money for college showed some developmental benefits.

\section{National Contexts and International Law}

The preceding three theoretical models tend to view student employment as the result of individual and family decisions. Such views offer limited insights into cross-national differences in the extent and impact of student employment. By contrast, Post and Pong $(2000,2009,2011)$ conceptualized student employment, and its relationship with academic achievement, as a multi-level process. From this perspective, a country's socioeconomic conditions can affect student employment such that families in poorer countries often need to use their children's time for meeting basic needs. In such contexts, children may be expected to work. In addition, these socioeconomic conditions may affect the consequences of student employment for school performance. In countries where norms of child protection have not taken hold, students may be more likely to perform arduous and sometimes even dangerous physical work that has negative consequences for their school work.

National policy contexts can also affect the extent and impact of student employment beyond a country's socioeconomic conditions. For example, compulsory school attendance laws and public spending on education may induce school attendance in place of child labor. Public policies may also operate through a variety of incentives, including free breakfast and lunch programs, voucher systems, and joint school-apprenticeship programs that pay students a wage (Post 2011). Additionally, in countries where there is little public educational assistance (e.g., publicly funded school feeding programs and vouchers), children who work may be more likely to suffer in terms of low achievement. In such settings, national policy environments may play an important role in affecting student employment and buffering the negative consequences of student employment.

Furthermore, a country's normative environment may likely shape the consequences of student employment for school achievement as well (Post 2011). For example, if work is seen as an expression of a cultural norm and if many students engage in part-time work, then the consequences of student employment for school performance may be less detrimental because families' and schools' expectations may accommodate each other. For example, parents may encourage out-of-school work experiences, while teachers may adjust the pace of instruction or reduce students' homework load. Where student employment is prevalent, schools and tests may also reflect career-oriented curriculum. By contrast, in countries where working while attending school is unacceptable, and very few students engage in part-time work, the consequences of student employment for academic performance may be substantial because schools would be less accommodating of the few students who work after school.

What can we expect about the ways that international laws shape the prevalence and effects of student employment? Some research suggests that international treaty commitments provide civil society with the tools and resources to force relevant reforms within a country (Boyle and Kim 2009; Hafner-Burton and Tsutsui 2005). For example, Boyle and Kim 
(2009) showed that ratification of child and human rights treaties, including the United Nation's International Covenant on Economic, Social, and Cultural Rights (ICESCR), Convention on the Rights of the Child (CRC), and ILO Minimum Age Convention (No. 138), had an indirect (but not direct) positive effect on child rights outcomes, including child labor. Ratifying the treaties early on was associated with greater increases in national linkages with child rights international non-governmental organizations (INGOs), and the presence of child rights INGOs was associated with improved implementation of child rights, including decreases in rates of child labor. These findings suggest that international policy contexts may promote national mobilization and the development of cultural and political contexts that have positive consequences for children.

Consistent with this past research, we similarly suspect that ratifying ILO Convention No. 138 could affect the extent and impact of student employment by regulating the minimum age at which children may be admitted to the workforce as well as certain types of dangerous work including mining, construction, and commercial farming. The goal of Convention No. 138 is to eradicate most forms of employment by young people below a minimum age (usually 15) and in all cases below the age of compulsory schooling. Equally important, Convention No. 138 proscribes certain types of work for children which are seen as dangerous and which can interfere with education. Upon formal ratification in each ILO party state, the terms of Convention No. 138 supersede national legislation such that national laws must be made consistent with the Convention. In practice, this means that, upon ratification of the Convention, work is not considered "legal" if it conflicts with compulsory schooling during the age ranges in which schooling is legislated in each member country. Countries which establish age ranges for compulsory schooling are compelled, once they formally ratify the Convention, to legislate protections and restrictions on children's employment such that their work will not interfere with compulsory education. Under one interpretation, ratifying ILO Convention No. 138 may itself affect children's health and educational outcomes by preventing and protecting them from working at various dangerous jobs. Alternatively, we may view a country's ratification of Convention No. 138 as the manifestation and expression of a pervasive view of what ought to be considered "normal" for children. Under either interpretation, we would hypothesize a difference in the employment-achievement relationship between countries that did and did not ratify Convention No. 138.

Of course, many types of "work" that students perform are unregulated and performed exclusively in the home or for the family, and these types of work would be less affected by the ratification of Convention No. 138. Unfortunately, as will be described below, TIMSS data do not allow us to identify the type of paid work students are performing. This limits our ability to gauge the impact of particular types of employment. Yet, TIMSS data do allow us to distinguish between children's paid work, presumably outside home, and work at home (e.g., family farming, household chores, or care of younger siblings). This distinction can be useful in assessing which types of work are most and least detrimental.

The foregoing discussion highlights the role of national and international policy contexts in explaining cross-national variations in student employment and its consequences for academic performance. Yet it remains to be seen whether such policy contexts really matter. 
Although Post and Pong (2000) examined cross-national differences in student employment and its impact on academic achievement by using data from the 1995 TIMSS, they did not test the role of national contexts in accounting for cross-national variations in the prevalence and effect of student employment. Their subsequent study (Post and Pong 2009), using TIMSS 2003, also looked at differences in the impact of student employment among a small set of countries, but their models did not specify national contexts that might condition the prevalence and impact of student employment.

In this article, we build on and extend the past literature by investigating whether national and international policy contexts relate either to the prevalence or to the impact of student employment, net of student background characteristics and national socioeconomic conditions. The current research has four specific aims. Using data from TIMSS 2003, our first aim is to document cross-national differences in the prevalence of student employment. The second aim is to document how the relationships between student employment and math and science performance vary by countries. The third aim is to examine whether national policy contexts are related to student employment. The fourth and most important aim is to examine whether the relationships between student employment and academic performance vary across countries, depending on a country's context.

\section{DATA AND METHODS}

\section{Data and Sample}

We used data from the 2003 international TIMSS database for eighth-grade students, whose average age is approximately 14.5 years old. ${ }^{6}$ TIMSS has made possible extensive, largescale international assessments of student achievement since 1995, with 47 countries (or school systems) around the world participating in 2003 (Mullis et al. 2004). TIMSS employs a stratified sampling design in which each participating country randomly samples the schools to be tested; one class is randomly chosen from each of these schools; and all students within the randomly selected class are tested in both math and science, yielding a nationally representative sample of students for each country (Mullis et al. 2004). In addition to math and science achievement scores, TIMSS offers a variety of information on the background of students, teachers, and school principals. Given the rigorous procedures taken to ensure high-quality sampling and testing in all countries and the standardized procedures to ensure comparability across countries, the TIMSS student performance and background data are comparable across countries and all TIMSS assessments (Mullis et al. 2003).

For the current study, we focused only on eighth-grade students because there was no measure of student employment in the fourth-grade assessment in 2003. We further restricted our analyses to those students who had valid information about student employment and background characteristics. We excluded England, Palestine, and Scotland due to missing data on the country-level variables. We also excluded Chinese Taipei (Taiwan) because it is not a member of the ILO. Finally, we excluded Morocco, where an extremely high proportion of eighth-grade TIMSS participant students (80\%) self-reported

\footnotetext{
${ }^{6}$ We chose TIMSS over other international data such as the Programme for International Student Assessment (PISA) because PISA does not include information about student employment.
} 
working at a paid job, because we were not confident that the responses accurately reflect students' activities in that country. Indeed, investigations based on both labor surveys and household living standards surveys indicate very small percentages of students combine work with schooling in Morocco (UNICEF-ILO-World Bank 2004). Our data restrictions left us with an analytic sample of 173,072 students in 42 countries (see Table 1 for the list of countries included in the analyses).

\section{Measures}

Student Employment-Student employment was based on a question asking how much time students spent working at a paid job before or after school on a normal school day. ${ }^{7}$ The original responses included (1) no time, (2) less than 1 hour, (3) 1-2 hours, (4) more than 2 but less than 4 hours, and (5) 4 or more hours. We created a dichotomous variable indicating whether students ever worked at a paid job on a normal school day by collapsing these categories into no time $(=0)$ vs. at least some time $(=1)$. There are two rationales for using the dichotomous measure of student employment. First, we believe that, if the national policy contexts such as the ILO ratification indeed matter for student employment, it would likely affect student employment itself, rather than its intensity. Second, prior research using the 1995 TIMSS data found that even a low level of work intensity was negatively related to academic achievement in every country (Post and Pong 2000) and our preliminary analyses (results available on request from the authors) confirmed this finding. ${ }^{8}$ We used this dichotomous variable of student employment as the dependent variable when studying cross-national variations in the prevalence of student employment, and then used this variable as an independent variable when examining the relationship between student employment and academic achievement.

Academic Achievement-TIMSS assesses students' knowledge of a wide array of content and cognitive domains in math and science especially based on school curricula (Mullis et al. 2003). In other words, rather than measuring student achievement against the norms of any particular national curriculum standard, the TIMSS measures student performance or "proficiency" in math and science among eighth-grade students for a common international set of skills (Mullis et al. 2003). The tests contain questions asking students to select appropriate responses or to solve problems by constructing their own answers. Both math and science proficiencies were measured by five plausible values with a scale having an international mean of 500 and an international standard deviation of 100.

\footnotetext{
${ }^{7}$ We should acknowledge that the particular activities which students report as a "paid job" may differ across countries. This is a common problem for the measurement of all cross-national activities studied through international assessments (e.g., after-school tutoring, school bullying or student engagement). However, as compared with many other activities queried in TIMSS or PISA questionnaires, a question about of whether or not the student worked for money is probably more universally understood. Furthermore, TIMSS 2003 did not ask students about their weekend work. As a result, we were unable to address whether weekend work differently or similarly affected academic performance compared to weekday work. Accordingly, it is unclear what consequences the omission of the information about weekend work may have on our overall findings. Yet, as the zero-sum model argues, if student employment reduces time and energy that could be otherwise spent on studying, one potential consequence of the omission of the information about weekend work may be that we have underestimated the negative consequences of student employment for academic performance. In such a case, our measure of employment only on school days would be a conservative estimate.

${ }^{8}$ We tested the "threshold model" by using the original, ordinal measure of intensity of student employment in addition to the dichotomous measure of student employment and found that even a few hours spent on paid jobs had negative consequences on academic performance in most countries. Furthermore, testing the threshold model did not change the overall findings with respect to the national contexts.
} 
We examined both math and science proficiencies as dependent variables. To do so, we simultaneously used the five plausible values to generate correct standard errors for each subject, following the recommendations of TIMSS (Martin 2005) (see Appendix A for mean math and science achievement for each country).

Country-Level Context Variables-Building on our previous discussion, we included several variables that measure national and international policy contexts concerned with education and child labor. First, we included GDP per capita in 2003 (current US dollars) to examine whether a country's socioeconomic condition was associated either with student employment or with the relationship between employment and academic performance. We transformed GDP per capita into the natural logarithm to resemble a normal distribution. Second, we included the duration of compulsory education (years) and public expenditure on education as a percentage of GDP. The purpose of this indicator was to measure the government's commitment and support of education. Specifically, high values of duration of compulsory education, and high public expenditure on education, both indicate strong national support for education within a country, and this may benefit working students. All of these three measures (i.e., GDP per capita, duration of compulsory education, and public expenditure on education as a percentage of GDP) were drawn from the data sources provided by the UNESCO Institute for Statistics. ${ }^{9}$ Next, we included our main indicator of interest in this article: a dichotomous measure of the regulation of children's employment, indicating whether a country had ratified ILO Convention No. 138 by the time students in the 2003 TIMSS had begun school (in 1995). ${ }^{10}$ Additionally, we included the national prevalence of student employment as a way to control for the degree of the cultural norms and expectations toward student employment. This variable was measured by the aggregate percent of students working at paid jobs within a country on a basis of the 2003 TIMSS.

In Table 1, we present the descriptive statistics of the country-level variables included in our analyses. We also present the correlation matrix among the country-level variables in Appendix Table B. As indicated, the average GDP per capita among the 42 countries ranged from approximately 1,000 US dollars (Ghana) to approximately 38,000 US dollars (Norway). Compulsory education ranged from 5 years (Iran) to 13 years (Flemish Belgium). The average public expenditure on education as a percentage of GDP ranged from $2.1 \%$ (Armenia) to $9.5 \%$ (Botswana). Out of 42 countries, 13 countries (31\%) had legally ratified the ILO Convention No. 138 in 1995. Finally, the average percentage of eighth-grade students working at a paid job while attending school was $27.1 \%$, ranging from $3.9 \%$ (South Korea) to $70.5 \%$ (Italy). We examine the national level of student employment in a greater detail in the Results section.

\footnotetext{
${ }^{9}$ Note that for some countries whose information was unavailable for these three variables in 2003, we used information available for adjacent years.

${ }^{10}$ We recognize, of course, that simply because a country has ratified Convention No. 138 does not mean that it will be enforced or translated into effective laws and policies. It is also likely that the ratification of the ILO Convention No. 138 is endogenous and produced by cultural, political, and economic contexts that may themselves shape student employment behaviors and their consequences. However, as noted, literature suggests the importance of policy in shaping the political and cultural environment which then has a direct impact on children's outcomes (Boyle and Kim 2009; Hafner-Burton and Tsutsui 2005). In short, we believe that the formal ratification in 1995 is a useful summary indicator of the national context for student employment among TIMSS participant students.
} 
Student-Level Control Variables-Under debate in many studies about student employment is the issue of whether student employment has a causal effect on academic performance or whether the observed effect is due to preexisting differences in, for example, prior achievement, socioeconomic background, and educational aspirations between working and non-working youth. ${ }^{11}$ Past research has underscored the need to control for family background and student characteristics that may be correlated with student employment and academic achievement when studying the relationship between student employment and academic achievement.

Accordingly, we included family background and student characteristic variables as control variables. These control variables included (1) parental education, (2) the number of books at home, (3) gender, (4) age, and (5) educational expectations. ${ }^{12}$ In addition, as noted, we controlled for (6) students' work at home in order to distinguish from paid work outside the home. ${ }^{13}$ However, as a cross-sectional survey, TIMSS does not allow us to control for prior achievement, which is probably the most important variable for identifying a causal relationship between employment and achievement. Without prior achievement, it is difficult to determine whether student employment affects academic performance, or vice versa. We must acknowledge that low-achieving students may become relatively less interested in school and thus become more likely to engage in work as compared with highachieving students. While we acknowledge the lack of information on prior achievement as a limitation of our study, we hoped to address this issue by additionally controlling for (7) doing homework, (8) enjoying learning math and science, and (9) liking school. All these control variables are positively related to academic achievement (see Appendix Table B for descriptive statistics of the student-level control variables for each country). ${ }^{14}$ As such, we made our best efforts to control for preexisting differences between students who combined work and schooling and students who did not by making the most use of TIMSS data.

\section{Analytic Strategies}

We implemented four analytic strategies corresponding with the four research aims. First, to examine how student employment varied across countries, we estimated the prevalence of student employment based on descriptive statistics for each country.

\footnotetext{
${ }^{11}$ Staff and Mortimer 2007; Staff et al. 2010; Warren et al. 2000; Willis and Rosen 1979.

${ }_{12}$ Parental education was based on the student's report of the highest level of father's and mother's education. The original responses were (1) did not finish International Standard Classification of Education (ISCED) 1 (primary education), (2) ISECD 1, (3) ISCED 2 (lower secondary), (4) ISCED 3 (upper secondary), (5) ISCED 4 (non-tertiary post-secondary), (6) ISCED 5B (vocational tertiary), (7) ISCED 5A (theoretically oriented tertiary and post-graduate) first degree, (8) beyond ISCED 5A, ad (9) I don't know. We collapsed these responses into three categories: high school or less (reference group) vs. university/college vs. I don't know. The number of books in home was measured as follows: (1) $1=0-10$, (2) $2=11-25$, (3) $3=26-100$, (4) $4=101-200$, and (5) $5=$ more than 200 books and included as a continuous variable. Gender was measured by the students' self-reported sex (female $=1$ vs. male $=0$ ). Age was also measured by the students' self-reported age. Educational expectations were based on students' reports of how far in school they expected to go. The original responses for educational expectations included (1) ISCED 3, (2) ISCED 4B, (3) ISCED 5B, (4) ISCED 5A, first degree, (5) beyond ISCED 5A, first degree, and (6) I don't know. As with parental education, we collapsed these responses into three categories: high school or less (reference group) vs. university/college vs. I don't know.

${ }^{13}$ Like student employment, doing jobs at home was measured by a question asking how much time students spent doing jobs at home before or after school on a normal school day, and we dummy-coded the original responses into no time $(=0)$ versus at least some time $(=1)$.

${ }^{14}$ Doing homework was also measured by a question asking how much time students spent doing homework before or after school on a normal school day, and we dummy-coded the original responses into no time $(=0)$ versus at least some time $(=1)$. Enjoying learning math/science and liking school were based on students' response on a four-point scale (ranging from "strongly disagree (=1)" to "strongly agree (=4)") of how strongly they agreed with each of the following statements: "I enjoy learning math," "I enjoy learning science," and "I like being in school."
} 
Second, to investigate how the relationships between student employment and academic performance varied between countries, we estimated ordinary least squares (OLS) regressions for each country for both math and science achievement. For the OLS regression analyses, we estimated two models: the first model included only the student employment variable as an independent variable and the second model additionally included the student background control variables. The aim was to examine the unadjusted and adjusted differences in academic achievement between students who combined work and study and students who did not work. For these descriptive and OLS regression analyses, we applied the final student weights (TOTWGT) for each country to make results generalizable to the student population within each country.

Third, to examine whether the national contexts were associated with student employment, we used a hierarchical generalized linear model (HGLM) approach, which is appropriate to analyze the nested nature of the TIMSS data and dichotomous outcome variables such as student employment (Raudenbush and Bryk 2002). As a first step, with the pooled data of 42 countries, we estimated a null model by using student employment as the dependent variable but with no predictors to examine the extent to which the probability of student employment varied across countries (results available upon request). In a second step, we added all student- and country-level variables to examine the relationships between the national contexts and the likelihood of student employment, controlling for the student background variables. ${ }^{15}$ While we centered all of the student-level control variables around the group mean, we centered all of the country-level variables around the grand mean.

Fourth, and finally, we examined whether the relationships between student employment and math and science achievement varied across countries, depending on national context variables. To do this, we employed a two-level hierarchical linear model (HLM) technique (Raudenbush and Bryk 2002) with the pooled data of 42 countries. We first fitted a model by using achievement as the dependent variable only with the student employment variable as a predictor. The aim was to examine not only the extent to which academic achievement varied across countries, but also the extent to which the relationship between student employment and academic achievement varied across countries (i.e., intercept-and slope-asoutcomes models) (Raudenbush and Bryk 2002). ${ }^{16}$ Next, we added all of the other studentand country-level variables for both intercept and slope-as-outcomes models. ${ }^{17} \mathrm{We}$ estimated fixed effects for all student-level control variables. Like for the HLGM analyses, we centered all of the student-level control variables including student employment around the group mean, and all of the country-level variables around the grand mean, respectively. Following the recommendations of TIMSS (Martin 2005), we applied the final student weights (SENWGT) to prevent countries with large samples from disproportionally affecting the results for the HLGM and HLM analyses. ${ }^{18}$

${ }^{15}$ We used the average score for the variable indicating enjoyment of learning math and science. 


\section{RESULTS}

\section{Descriptive Results}

Cross-National Variations in the Prevalence of Student Employment-We begin with a description of the prevalence of student employment cross-nationally. Figure 1 presents the proportion of eighth-grade students who worked at a paid job before and after school on a normal school day by country. As noted, on average, almost 3 out of 10 eighthgrade students in 42 TIMSS 2003 participating school systems worked at a paid job while attending school. Yet there were considerable cross-national variations in the prevalence of student employment. At one extreme, in Italy, approximately $71 \%$ of the eighth-grade students combined work and schooling. At the other extreme, only about $4 \%$ of the eighthgrade students combined work and schooling in Korea. In sum, while a substantial proportion of students combined work and schooling, the prevalence of student employment differed by country.

\section{Cross-National Variations in the Relationship of Student Employment and Academic Performance-Next, we examine cross-national differences in the} relationship between student employment and academic performance. Figure 2 shows unadjusted gaps and gaps adjusted for student background characteristics in terms of mathematics. With the exception of Italy, there were significant gaps in math performance between students who combined work and schooling and students who did not in almost all countries before controlling for the other student background characteristics. Once we controlled for the student background characteristics, such gaps in math achievement became much smaller but they remained statistically significant in all countries, again with the exception of Italy. The math achievement gap clearly varied across countries. For example, the adjusted difference in math achievement between students who combined work

\footnotetext{
16 This model was specified as follows: Student -level:
}

$$
(\text { academic achievement })_{i j}=\beta_{0 j}+\beta_{1 j}(\text { student employment })+r_{i j}
$$

where $\beta_{0 j}$ represents the average achievement of the country $j$ adjusted for student employment, $\beta_{1 j}$ the effect of student employment, and $\mathrm{r}_{i j}$ random errors.

Country-level:

$$
\begin{aligned}
& \beta_{0 j}=\gamma_{00}+u_{0 j} \\
& \beta_{1 j}=\gamma_{10}+u_{1 j}
\end{aligned}
$$

\footnotetext{
where $\gamma_{00}$ is the mean achievement across the countries, $\gamma_{10}$ the average student employment-achievement slope, $u_{0 j}$ the unique effect of country $i$ on mean achievement, $u_{1 j}$ the unique effect of country $i$ on the student employment-achievement slope (i.e., slope). ${ }^{17}$ Although we do not present results here, we examined the interaction effect of gender and student employment on academic performance, as literature suggests that girls and boys tend to work at different types of jobs and thus the impact of paid work on academic achievement differs depending on gender (Post and Pong 2010). However, we did not find a significant interaction effect of gender and employment. We also tested each of the interaction effects between the ILO ratification variable and the other countrylevel variables for both student employment and academic performance as the outcomes. However, we did not find any significant interaction effects. Finally, we also tested the non-linear effect of each of the continuous country-level variables but again did not find any significant non-linear effect. All of these results are available from the authors upon request.

18 In TIMSS 2003, student senate weights, which transform the sum of the total student weights to 500 for each country, allow each country to contribute to the same amount to the cross national comparison (Martin 2005).
} 
and schooling and students who did not was approximately 46 points in South Africa, whereas the corresponding difference was only about 6 points in Lebanon.

We found similar patterns in science achievement, as shown in Figure 3. In other words, students who combined work and schooling lagged behind students who did not in terms of science achievement except in Italy. Although such gaps were much reduced once we controlled for the other student background characteristics, they remained statistically significant for all countries, again except for Italy. As with the working/non-working math achievement gap, the gap for science achievement varied across countries. In sum, while there were significant gaps in academic performance between students who combined work and schooling and students who did not work, the extent of the achievement gaps differed widely across countries. The next section attempts to account for the wide differences using national-level indicators.

\section{Results from Multilevel Analyses}

Student Employment-We first examine the extent to which national context and child labor regulation variables are related to the probability of student employment. Table 2 presents the results of the two-level HGLM. Somewhat surprisingly, the results showed that none of the national and international context variables, except for the GDP per capita, were positively associated with the likelihood of student employment. The GDP per capita was only slightly related to the likelihood of student employment (at the statistically significance level of .10). Specifically, the odds of engaging in part-time work were slightly smaller for students living in richer countries than for their counterparts in poorer countries.

In contrast to the limited explanatory value of national contextual variables, we found all individual background variables to be strongly associated with the likelihood of student employment. We found that students from more advantaged socioeconomic backgrounds (e.g., college educated parents, more books at home) were less likely to work at paid jobs after school, compared to students from less advantaged socioeconomic backgrounds (e.g., high school educated parents, fewer books at home). Female and younger students were less likely than were males and older students to work at paid jobs. Students who aspired to postsecondary education were less likely to combine work and schooling than students who aspired to high school or less. Notice that students who worked at home were also more likely to work at paid jobs, compared to students who did not work at home. By contrast, doing homework after school and high levels of enjoyment about learning math and science and liking being in school were associated with a decreased likelihood of working at paid jobs. The random component results showed that the student- and country-level variables explained approximately $6 \%$ of the country-level variance in the likelihood of student employment, compared with the null model with no predictors (results are not shown).

Academic Achievement-The final set of analyses examine whether the national and international policy context variables shape the relationship between student employment and academic achievement. Table 3 presents the results of a two-level HLM estimation for math (left column) and science achievement (right column). Because our interest lies in the relationship between student employment and academic performance, and how the national 
context variables shaped this relationship, our interpretations are focused on the coefficients of student employment and those of the country-level variables for the slope of student employment.

With respect to the relationship between student employment and academic performance, results showed that student employment was negatively associated with both math and science performance, even after controlling for the other student- and country-level variables. Specifically, combining work and schooling lowered both math and science achievement scores by approximately 25 points.

When it came to the relationship between national context variables and the slope of student employment, results showed that duration of compulsory education was positively associated with the slope of student employment for science performance (though only at a statistical significance level of .10). Compulsory school duration was not associated with math performance. Importantly, results showed that the ILO Convention ratification variable was positively associated with the slope of student employment for both math and science performance. In terms of math achievement, the fact that a country had ratified ILO Convention was associated with a 6 point reduction in the negative consequence of student employment. In other words, the average achievement of students who combined schooling and work in countries ratifying the ILO Convention averaged about 6 points higher than the scores of students with a similar background and work history who lived in countries that had not ratified this treaty convention by the year the child started school (in 1995). Meanwhile, the prevalence of student employment was positively related to the slope of student employment for math achievement but not for science achievement, indicating that the negative association between student employment and academic achievement tended to be smaller in a country where a higher proportion of students engaging in part-time work than elsewhere.

Before we further discuss these results, we briefly highlight the relationship between the national-level variables and the intercepts for math and science achievement. Unexpectedly, greater public expenditure on education was associated with lower achievement for math and science. As expected, however, higher GDP per capita was significantly related to higher achievement for both math and science. Finally, the higher prevalence of student employment was significantly associated with lower achievement for both math and science. The random components suggested that the student- and country-level variables explained approximately $48 \%$ and $44 \%$ of between-country variance in math and science achievement, respectively, and approximately $57 \%$ and $44 \%$ of between-country variation in the slope of student employment for math and science achievement, respectively.

\section{DISCUSSION}

Using data from TIMSS 2003, we found considerable cross-national variation in the likelihood of student employment among eighth-grade students. We also found that student employment was negatively associated with math and science achievement in most countries, even after controlling for student background characteristics. The finding of the negative consequences of student employment is consistent with most previous evidence, ${ }^{19}$ 
supporting the zero-sum model. In addition, we found that the magnitude of such negative associations varied considerably across countries, which confirms the past findings by Post and Pong (2000).

More importantly, through multilevel analyses, we found that the national level of student employment was negatively associated with math and science achievement above and beyond the individual level of student employment and other background characteristics. Some national contextual variables seem to ameliorate the negative consequences of student employment for academic performance, even after controlling for student background characteristics and a country's socioeconomic condition. For example, the negative association between student employment and math and science achievement was much smaller in countries ratifying ILO Convention No. 138 on child labor, as compared with the achievement gap elsewhere. As discussed, this finding may be attributable to the fact that ratifying ILO Convention No. 138 aims at preventing and protecting young students from working at various dangerous jobs. Alternatively, ratification may be endogenous and a manifestation of pervasive protections already in place by 1995 .

Why should the gap in math performance be smaller in countries where a higher proportion of students work? As described earlier, the smaller negative association between student employment and math performance in countries where large proportions of students work may be explained by positive views of work by families, teachers, and schools. Together, our findings suggest that the national and international contexts play an important role in moderating the negative consequences of student employment for academic performance, which are consistent with research findings highlighting the role of national and international policy contexts. ${ }^{20}$

Contrary to our expectation, we did not find that national and international contexts were directly related to the likelihood of student employment. Only a country's socioeconomic condition measured by GDP per capita was marginally associated with the likelihood of student employment. Although more research is needed to understand the role of national contexts in shaping the prevalence of student employment, it may be that other national contextual factors led to the ratification of Convention No. 138, and these unobserved and omitted variables also affected the net likelihood of paid employment. Indeed, Burstein (1991:346) noted that child labor is a "policy domain" and "such domains are to a considerable extent social constructions, created through interactions among organizations and given meaning by culture. Policy change takes place through the conjunction of three streams of activity moving fairly independently: problem recognition and agenda setting; the specification of policy options; and the politics of selecting among proposals and enacting legislation." In the case of ILO Conventions, the same political forces which cause the problem to be recognized and legislation to be enacted have undoubtedly exerted a direct effect on the willingness of parents and employers to permit many types of employment.

${ }^{19}$ Gunnarsson et al. 2006; Ray and Lancaster 2005; Singh et al. 2007; Zabaleta 2011

20 Boyle and Kim 2009; Hafner-Burton and Tsutsui 2005; Hampden-Thompson and Pong 2005; Park 2008; Pong et al. 2003; Xu 2008. 
The present study has several limitations that could be addressed in future research, and several that could not be addressed in the absence of longitudinal information. First, as noted in the Data and Methods section, the cross-sectional nature of TIMSS and the lack of information on prior achievement did not allow us to identify a causal link between student employment and academic performance. To better estimate the causal relationship between student employment and academic performance, future research should use longitudinal data that includes prior achievement as well as prior work experiences.

Second, our study investigated a limited number of national contextual variables. It is likely that other aspects of cultural, political, and economic contexts affect the extent and impact of student employment. For example, the overall level of educational attainment of the adult population may affect student employment such that a better-educated population may be likely to embrace more progressive and less traditional views on childhood and to embrace children's right to an education (Post 2011). It is also likely that high-stakes tests and academic pressure may combine to affect student employment and its impact on academic achievement (Post and Pong 2000, 2009). In other words, in a situation where high-stakes exams play an important role in gaining access to selective colleges or prestigious jobs so that competition and academic pressure is high, students may be least likely to work while attending school, and student employment may have a greater impact on academic achievement. Indeed, our analyses showed the lowest levels of student employment in the East Asian countries of our analysis (Korea, Singapore, and Hong Kong), where academic competition is known to be considerably high due largely to high-stakes exams (Byun, Schofer, and Kim 2012). Future research could investigate whether the high-stakes tests and academic pressure as well as other characteristics of national contexts affect student employment and other social activities and their consequences for academic performance.

Another opportunity for future researchers will be to consider school-level variables, which may have a more direct impact on student employment. In this study, we did not focus on local schools and communities in shaping student employment because our interests were in the roles of national contexts. However, lower-quality schools may provide no countervailing incentive for families to maintain their children in school in situations where children are needed to supplement scarce family income, and as a result, students attending low-quality schools may be more likely to work either exclusively or in addition to schooling than students attending high-quality schools (Post 2011). In this context, future research should investigate how various features of local schooling shape student employment and its relationship with academic performance.

Despite the limitations of our study, the present findings have implications for the role of national and international policy environments in reducing the negative consequences of student employment for academic achievement. The evidence suggests that comprehensive labor protection (indicated by ratification of Convention No. 138), even if it does not in itself directly decrease the likelihood of part-time work, can reduce the detrimental effect students' work has for their academic achievement. This research finding thus highlights the importance of policy environments in shaping children's lives outside of schooling and their educational outcomes. 


\section{Appendix}




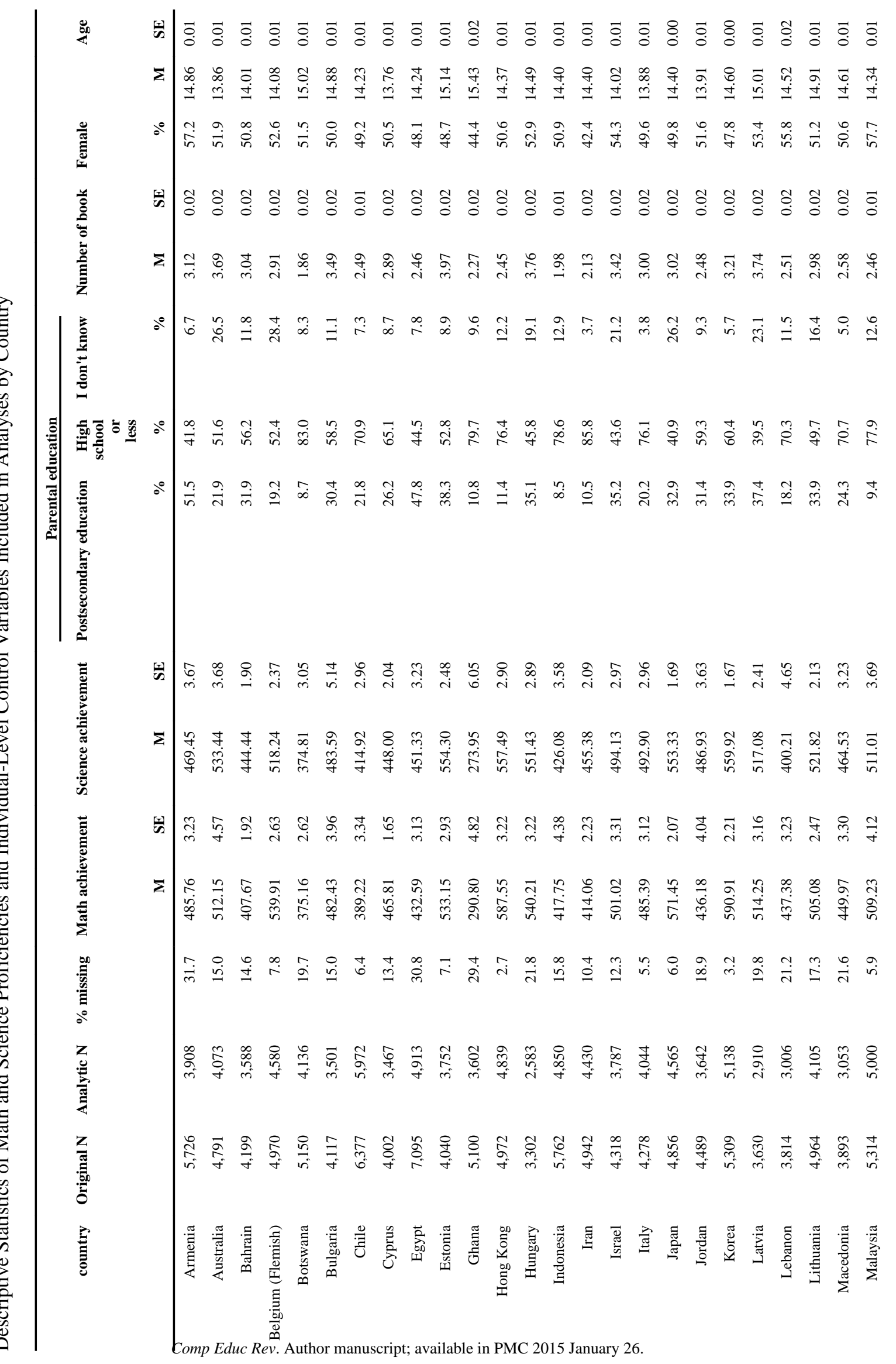




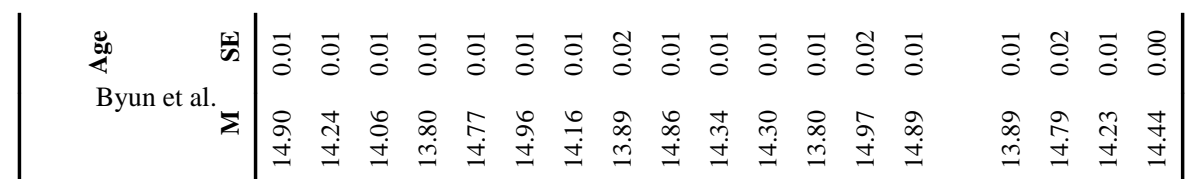

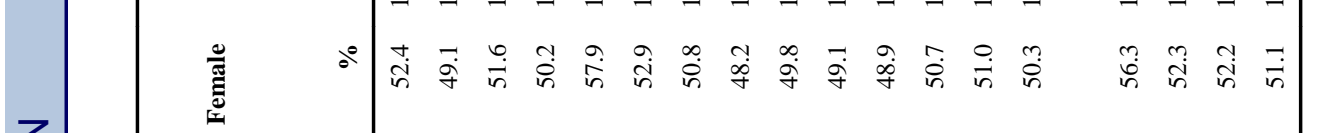

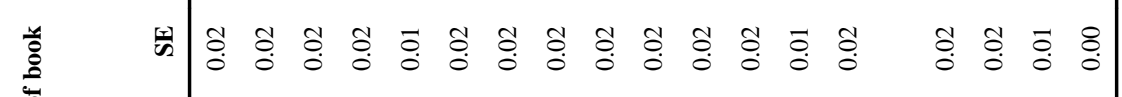

产

そ)

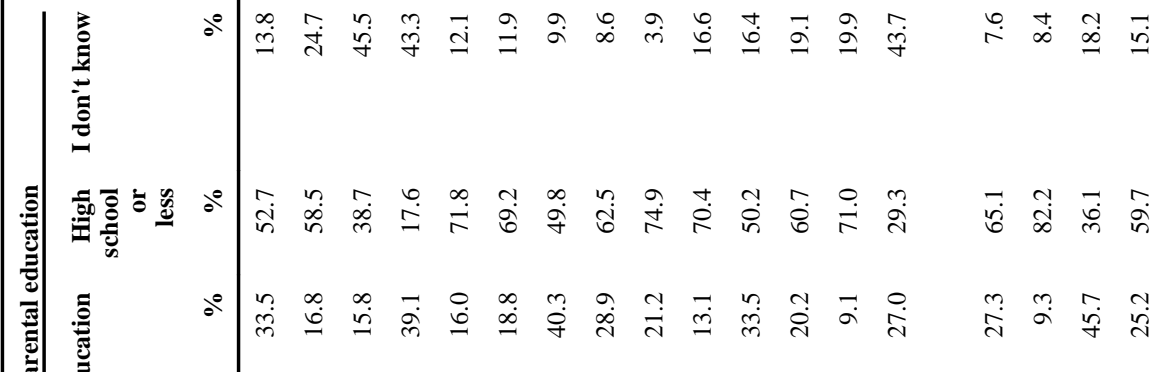

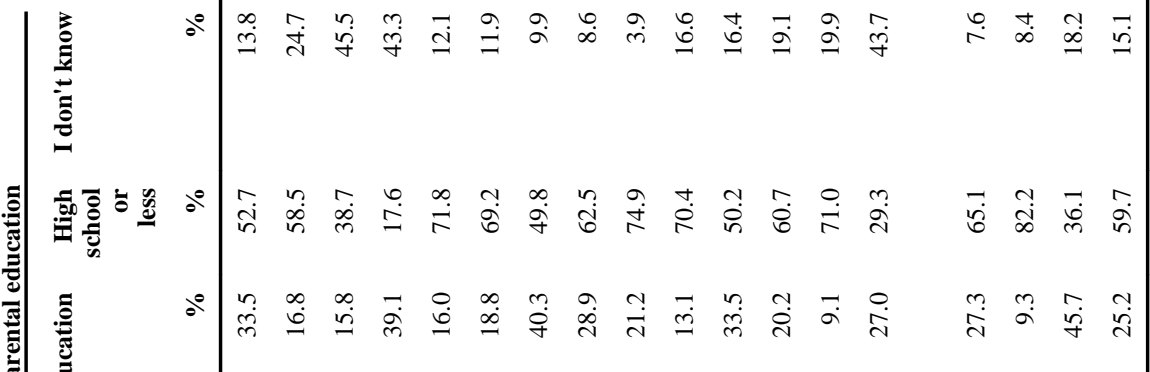

इ

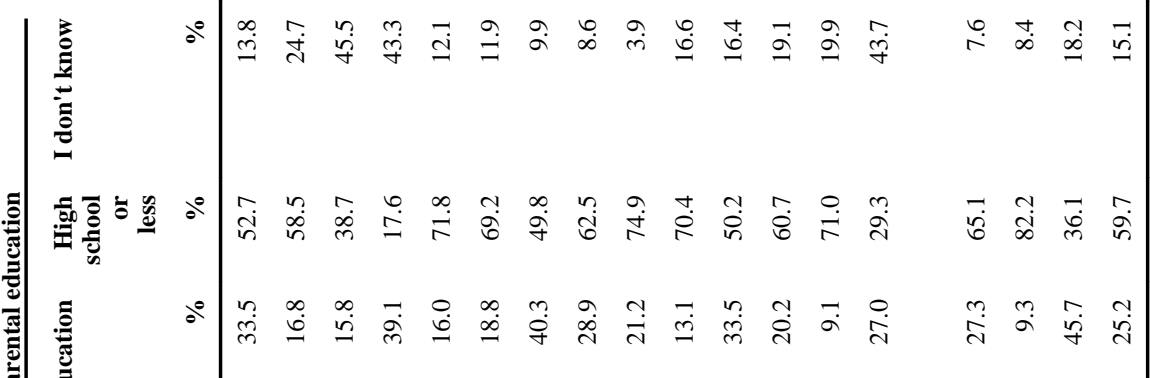

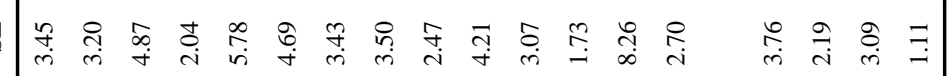

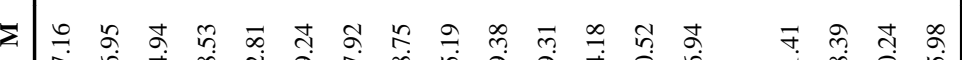

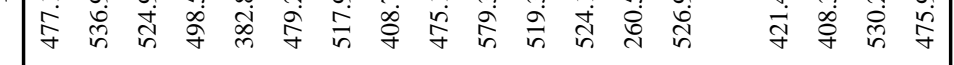

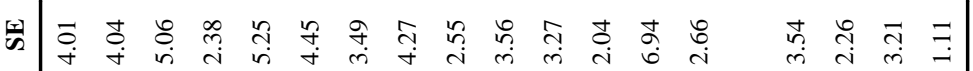
$\Sigma$ ก

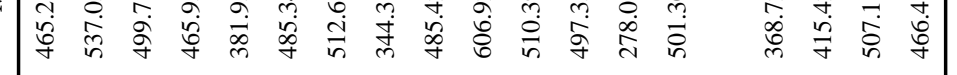

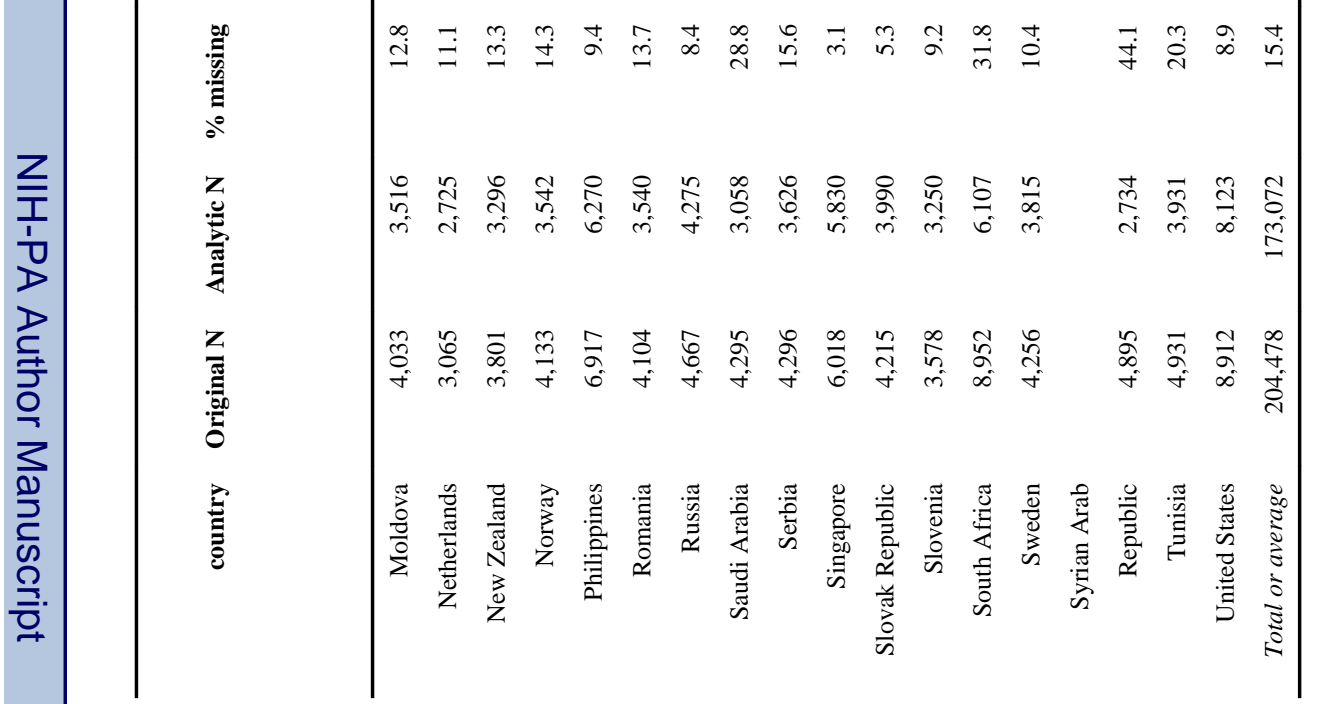

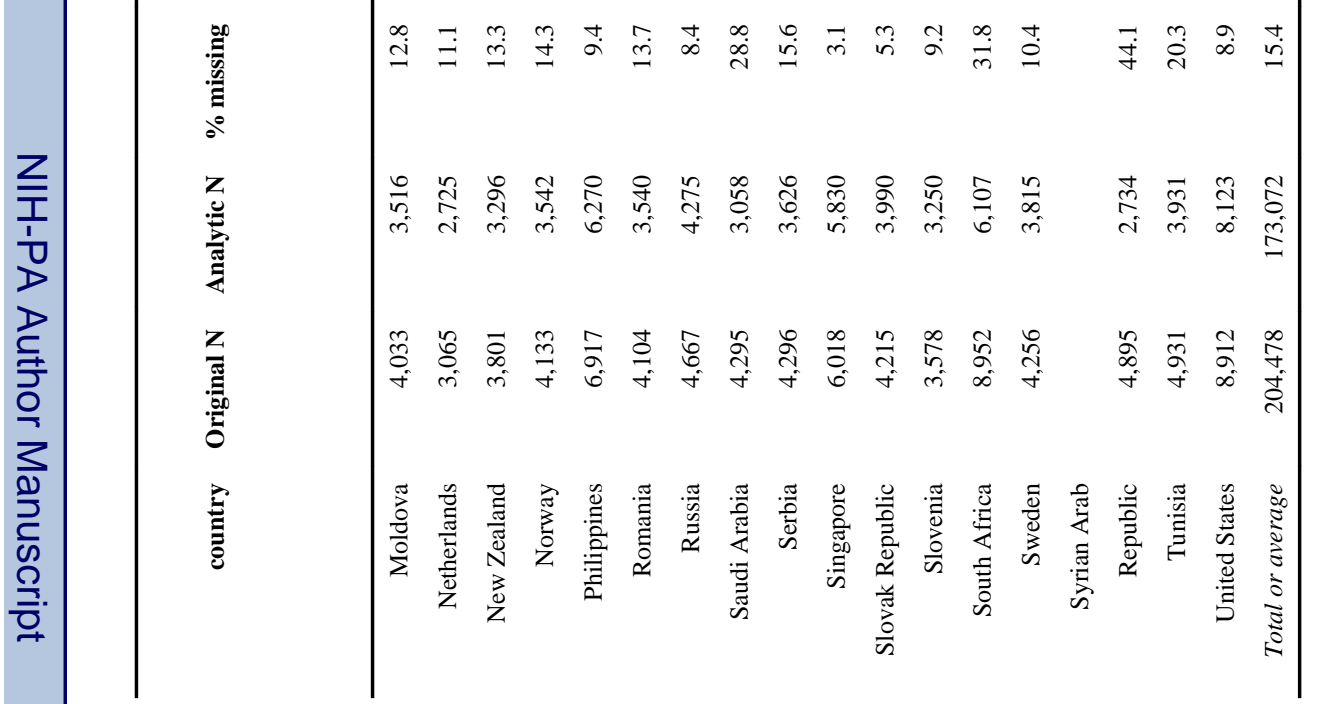

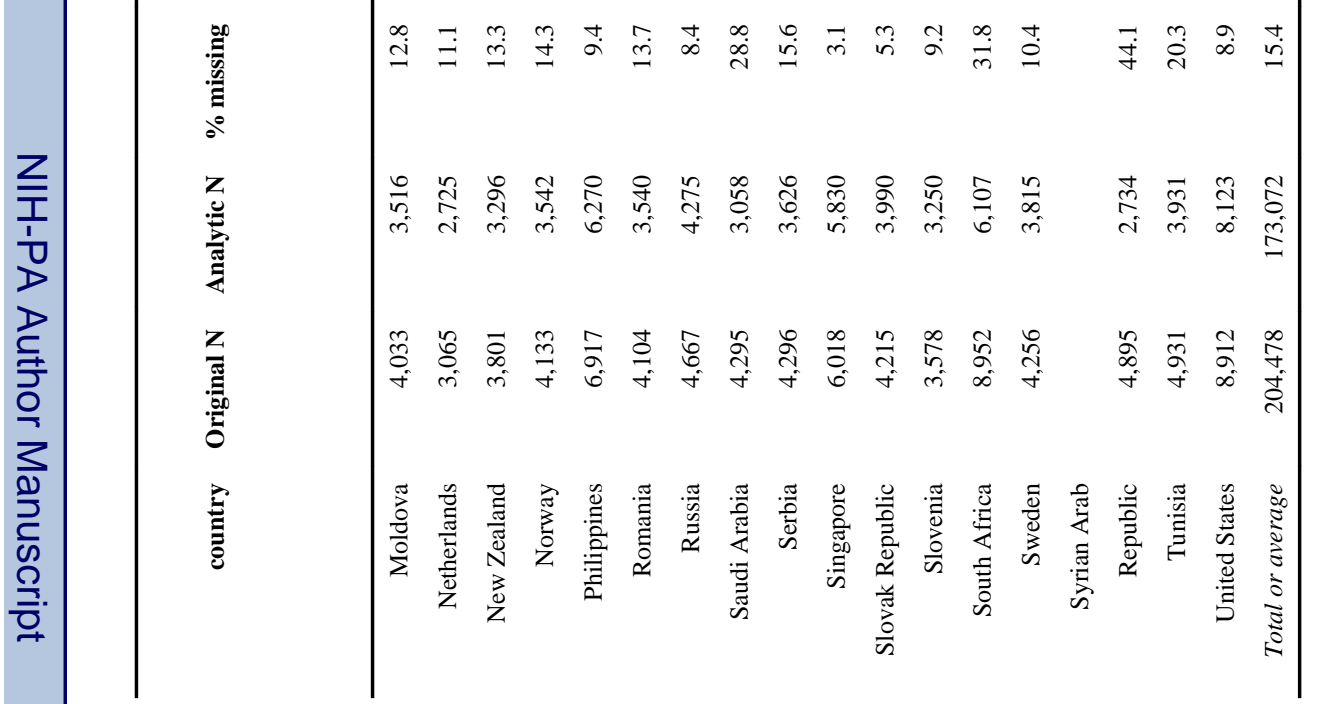

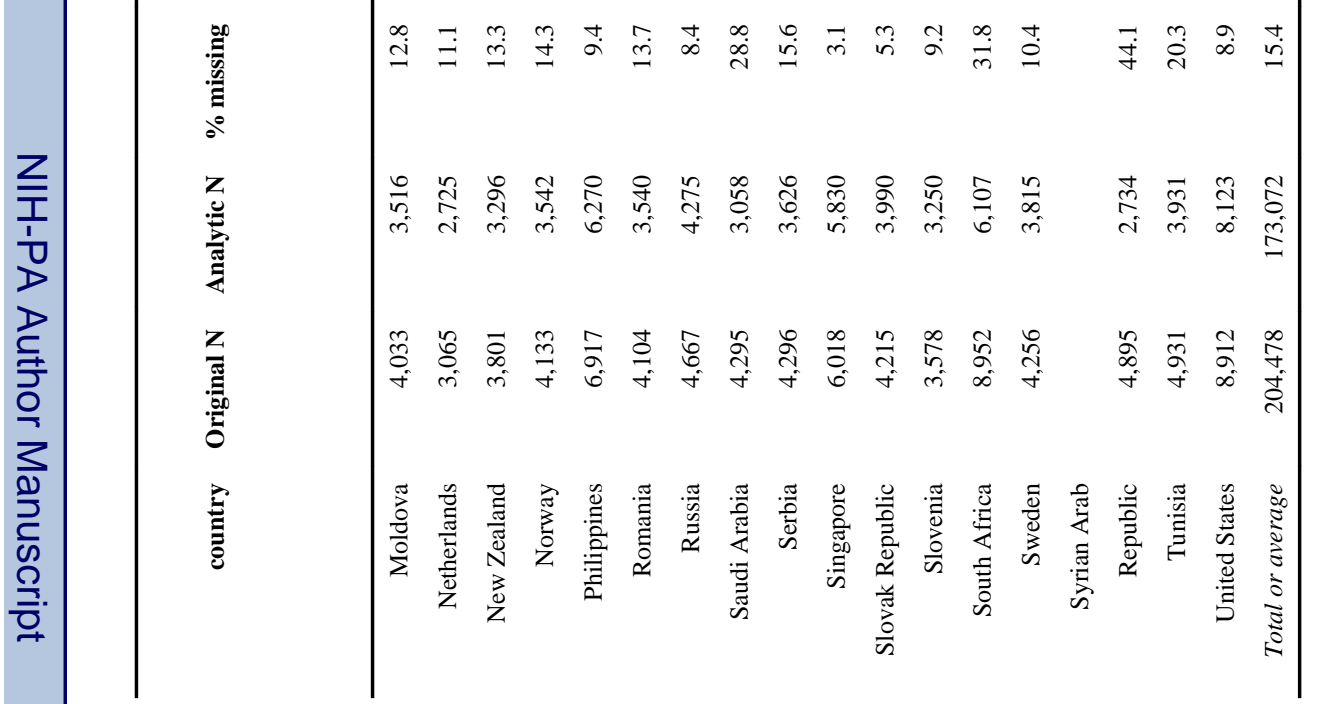

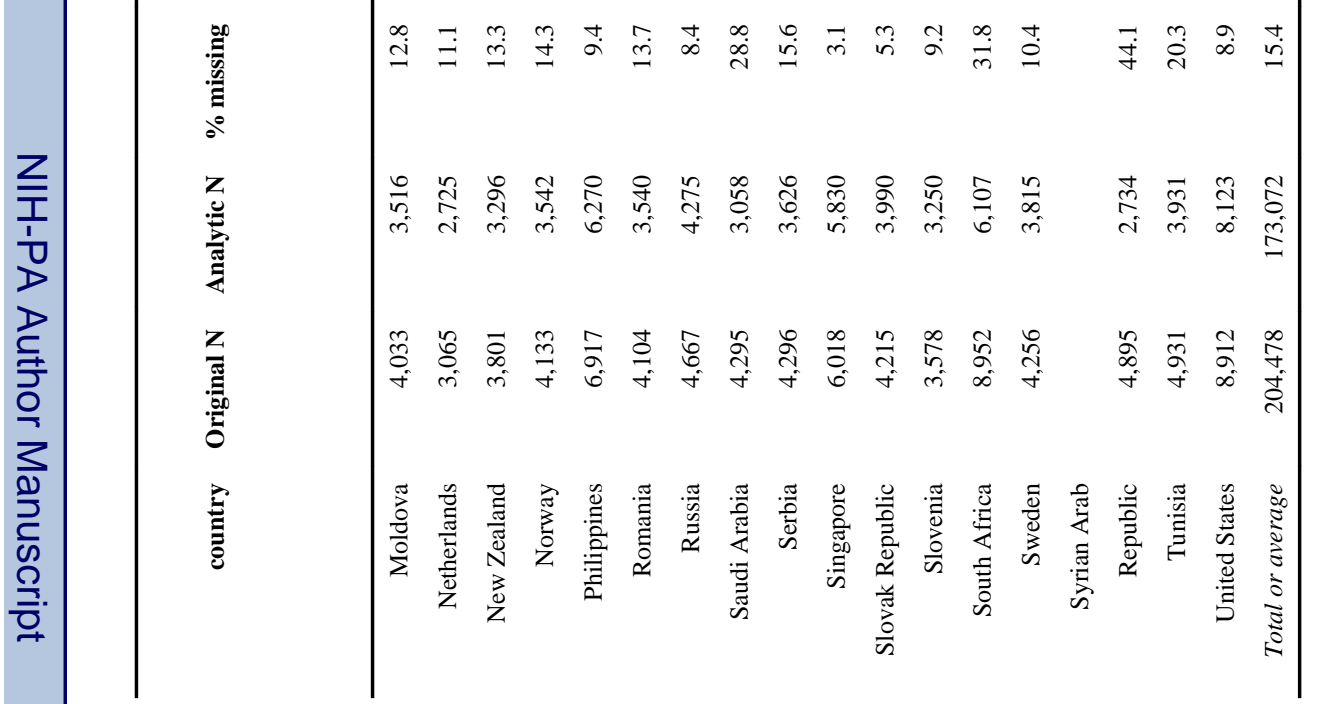

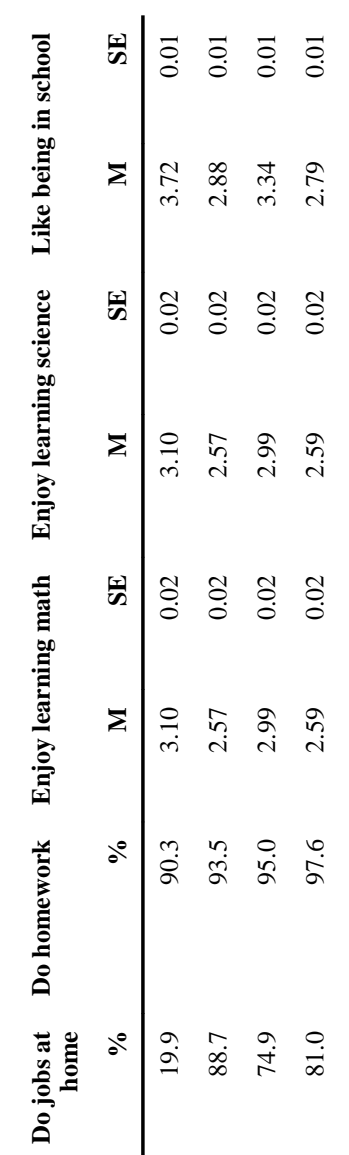

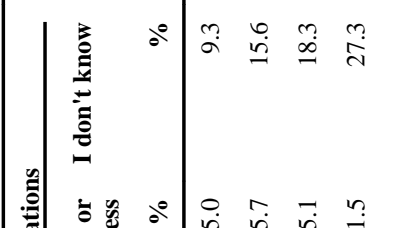
:

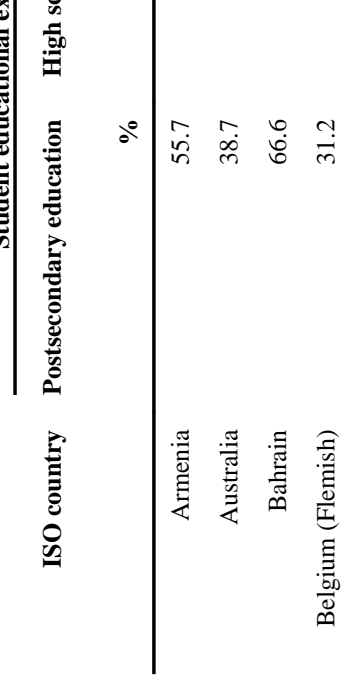




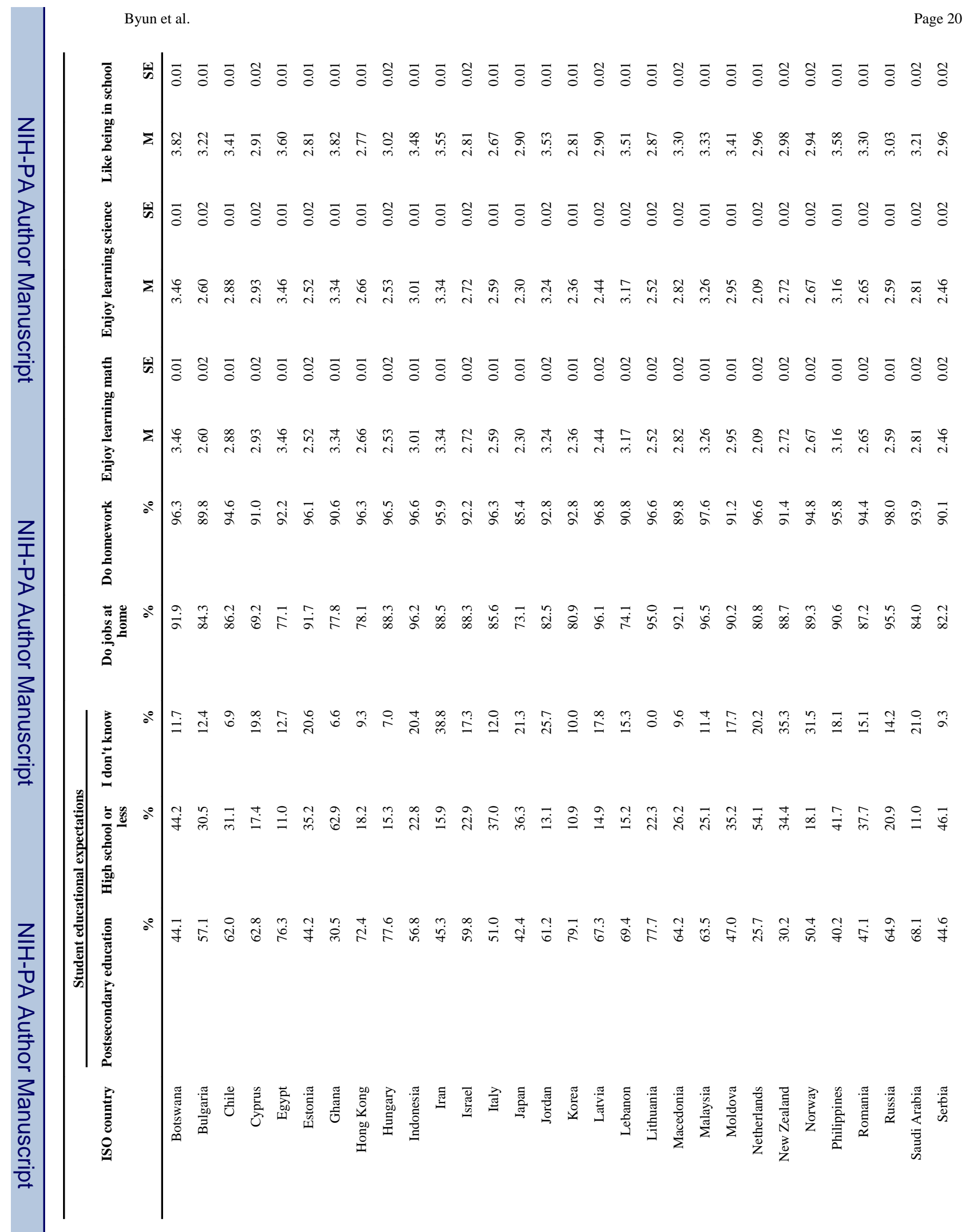

Comp Educ Rev. Author manuscript; available in PMC 2015 January 26. 


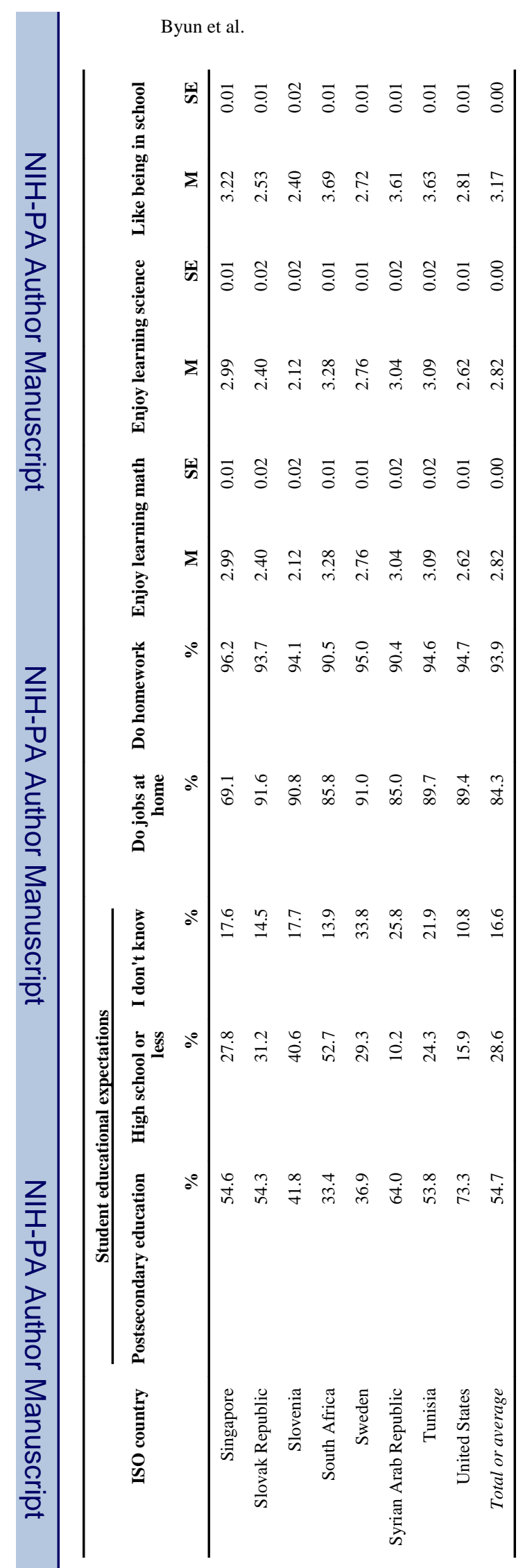

Comp Educ Rev. Author manuscript; available in PMC 2015 January 26. 


\section{Appendix Table B}

Correlation Matrix for the Country-Level Variables

\begin{tabular}{llllll}
\hline Variable & $\mathbf{1}$ & $\mathbf{2}$ & $\mathbf{3}$ & $\mathbf{4}$ & $\mathbf{5}$ \\
\hline 1. GDP per capita (logged) & - & & & & \\
2. Duration of compulsory education & $0.304^{\dagger}$ & - & & & \\
3. Public expenditure on education & $0.267^{\dagger}$ & $0.291^{\dagger}$ & - & & \\
4. ILO ratification & $0.300^{\dagger}$ & $0.291^{\dagger}$ & 0.101 & - & \\
5. Prevalence of student employment & -0.220 & -0.043 & -0.030 & 0.022 & - \\
\hline$N=42$ & & & & & \\
$N_{<}<10$ (two-tailed tests) & & & & &
\end{tabular}

\section{REFERENCES}

Boyle, Elizabeth Heger; Minzee, Kim. International Human Rights Law, Global Economic Reforms, and Child Survival and Development Rights Outcomes. Law \& Society Review. 2009; 43(3):45590.

Buchmann, Claudia. Frontiers in Comparative and International Sociology of Education: American Distinctiveness and Global Diversity. Frontiers in Sociology of Education. 2011:35-51.

Burstein, Paul. Policy Domains: Organization, Culture, and Policy. Annual Review of Sociology. 1991; 17:327-350.

Byun, Soo-yong; Schofer, Evan; Kim, Kyung-keun. Revisiting the Role of Cultural Capital in East Asian Educational Systems: The Case of South Korea. Sociology of Education. 2012; 85(3):21939.

Cawelti, John G. Apostles of the Self-Made Man. University of Chicago; Chicago: 1965.

D'Amico, Ronald. Does Employment During High School Impair Academic Progress? Sociology of Education. 1984; 57(3):152-64.

DeSimone, Jeff. Academic Performance and Part-Time Employment among High School Seniors. Topics in Economic Analysis \& Policy. 2006; 6(1):1-32.

Dumas, Christelle. Does Work Impede Child Learning? The Case of Senegal. Economic Development and Cultural Change. 2012; 60(4):773-93.

Goulart, Pedro; Bedi, Arjun S. Child Labour and Educational Success in Portugal. Economics of Education Review. 2007; 27:575-87.

Gunnarsson, Victoria; Orazem, Peter F.; Sanchez, Mario A. Child Labor and School Achievement in Latin America. World Bank Economic Review. 2006; 20(1):31-54.

Hafner-Burton, Emilie M.; Tsutsui, Kiyoteru. Human Rights in a Globalizing World: The Paradox of Empty Promises. American Journal of Sociology. 2005; 110:1373-411.

Hampden-Thompson, Gillian; Pong, Suet-Ling. Does Family Policy Environment Moderate the Effect of Single Parenthood on Children's Academic Achievement? A Study of 14 European Countries. Journal of Comparative Family Studies. 2005; 36(2):227-48.

Holgado, Daniel; Isidro Maya-Jariego, Ignacio Ramos; Jorge Palacio, Oscar Oviedo-Trespalacios; Romero-Mendoza, Vanessa; Amar, José. Impact of child labor on academic performance: Evidence from the program 'Educame Primero Colombia'. International Journal of Educational Development. 2014; 34:58-66.

Lee, Jennifer C.; Staff, Jeremy. When Work Matters: The Varying Impact of Work Intensity on High School Dropout. Sociology of Education. 2007; 80(2):158-78.

Lillydahl, Jane H. Academic Achievement and Part-Time Employment of High School Students. The Journal of Economic Education. 1990; 21(3):307-16. 
Marsh, Herbert W. Employment during High School: Character Building or a Subversion of Academic Goals. Sociology of Education. 1991; 64(3):172-89.

Marsh, Herbert W.; Kleitman, Sabina. Consequences of Employment during High School: Character Building, Subversion of Academic Goals, or a Threshold? American Educational Research Journal. 2005; 42(2):331-69.

Martin, Michale. O., editor. TIMSS 2003 User Guide for the International Database. TIMSS \& PIRLS International Study Center, Boston College; Chestnut Hill, MA:

McCoy, Selina; Smyth, Emer. So much to do, so little time part-time employment among secondary students in Ireland. Work, Employment \& Society. 2007; 21(2):227-46.

McNeal, Ralph B. Are Students Being Pulled out of High School? The Effect of Adolescent Employment on Dropping Out. Sociology of Education. 1997; 70(3):206-20.

Mortimer, Jeylan T.; Finch, Michael D.; Shanahan, Michael; Ryu, Seongryeol. Work Experience, Mental Health, and Behavioral Adjustment in Adolescence. Journal of Research on Adolescence. 1992; 2:25-57.

Mullis, Ina V.S.; Martin, Michael O.; Gonzalez, Eugenio J.; Chrostowski, Steven J. TIMSS 2003 International Mathematics Report. TIMSS \& PIRLS International Study Center, Boston College; Chestnut Hill, MA: 2004.

Mullis, Ina V.S.; Martin, Michael O.; Smith, Teresa A.; Garden, Robert A.; Gregory, Kelvin D.; Gonzalez, Eugenio J.; Chrostowski, Steven J.; O'Connor, Kathleen M. Assessment Framework and Specifications 2003. TIMSS \& PIRLS International Study Center, Boston College; Chestnut Hill, MA: 2003.

Park, Hyunjoon. Public Policy and the Effect of Sibship Size on Educational Achievement: A Comparative Study of 20 Countries. Social Science Research. 2008:874-87.

Pong, Suet-Ling; Dronkers, Jaap; Hampden-Thompson, Gillian. Family Policies and Children's School Achievement in Single-Versus Two-Parent Families. Journal of Marriage and Family. 2003; 65(3): 681-99.

Post, David; Pong, Suet-Ling. Employment During Middle School: The Effects on Academic Achievement in the U.S. And Abroad. Educational Evaluation and Policy Analysis. 2000; 22(3): 273-98.

Post, David; Pong, Suet-Ling. Student Labour and Academic Proficiency in International Perspective. International Labour Review. 2009; 148(1-2):93-122.

Post, David. Primary School Student Employment and Academic Achievement in Chile, Colombia, Ecuador and Peru. International Labour Review. 2011; 150(3-4):255-78.

Raudenbush, Stephen W.; Bryk, Anthony S. Hierarchical Linear Models: Applications and Data Analysis Methods. Sage; Thousand Oaks, CA: 2002.

Ray, Ranjan; Lancaster, Geoffrey. The Impact of Children's Work on Schooling: Multi-Country Evidence. International Labour Review. 2005; 144(2):189-210.

Rothstein, Donna S. High School Employment and Youths' Academic Achievement. Journal of Human Resources. 2007; 42(1):195-213.

Sabia, Joseph J. School-year employment and academic performance of young adolescents. Economics of Education Review. 2009; 28(2):268-276.

Schoenhals, Mark; Tienda, Marta; Schneider, Barbara. The Educational and Personal Consequences of Adolescent Employment. Social Forces. 1998; 77(2):723-61.

Singh, Kusum. Part-Time Employment in High School and Its Effect on Academic Achievement. Journal of Educational Research. 1998; 91(3):131-39.

Singh, Kusum; Chang, Mido; Dika, Sandra. Effects of Part-Time Work on School Achievement During High School. Journal of Educational Research. 2007; 101(1):12-22.

Staff, Jeremy; Mortimer, Jeylan T. Educational and Work Strategies from Adolescence to Early Adulthood: Consequences for Educational Attainment. Social Forces. 2007; 85(3):1169-94.

Staff, Jeremy; Schulenberg, JE.; Bachman, JG. Adolescent Work Intensity, School Performance, and Academic Engagement. Sociology of Education. 2010; 83(3):183-200. [PubMed: 20802795]

Tyler, John H. Using State Child Labor Laws to Identify the Effect of School-Year Work on High School Achievement. Journal of Labor Economics. 2003; 21(2) 
UNESCO. EFA Global Monitoring Report. UNESCO Publishing; Paris: 2002. Education for All: Is the World on Track?.

UNESCO. EFA Global Monitoring Report. UNESCO Publishing; Paris: 2012. Youth and Skills: Putting Education to Work..

UNICEF-ILO-World Bank. Understanding Children's Work in Morocco. Interagency Group on Understanding Children's Work; Florence, Italy: 2004.

Warren, John R.; LePore, Paul C.; Mare, Robert D. Employment During High School: Consequences for Students' Grades in Academic Courses. American Educational Research Journal. 2000; 37(4): 943-69.

Willis, Robert J.; Rosen, Sherwin. Education and Self-Selection. The Journal of Political Economy. 1979; 87(5):S7-36.

Xu, Jun. Sibship Size and Educational Achievement: The Role of Welfare Regimes Cross-Nationally. Comparative Education Review. 2008; 52(3):413-36.

Zabaleta, Mariela B. The Impact of Child Labor on Schooling Outcomes in Nicaragua. Economics of Education Review. 2011; 30(6):1527-39. 
$(\%)$

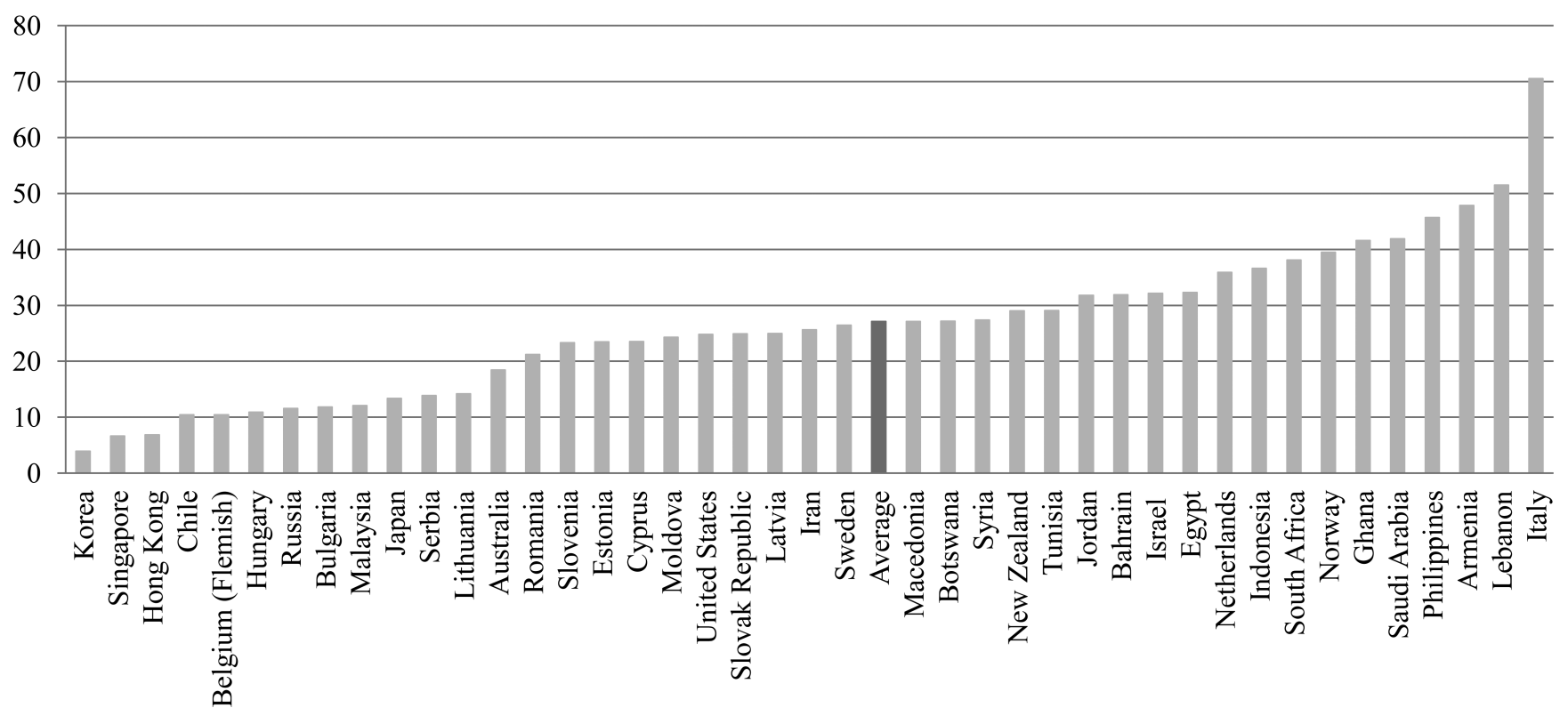

Figure 1.

Cross-National Variations in Prevalence of Student Employment 


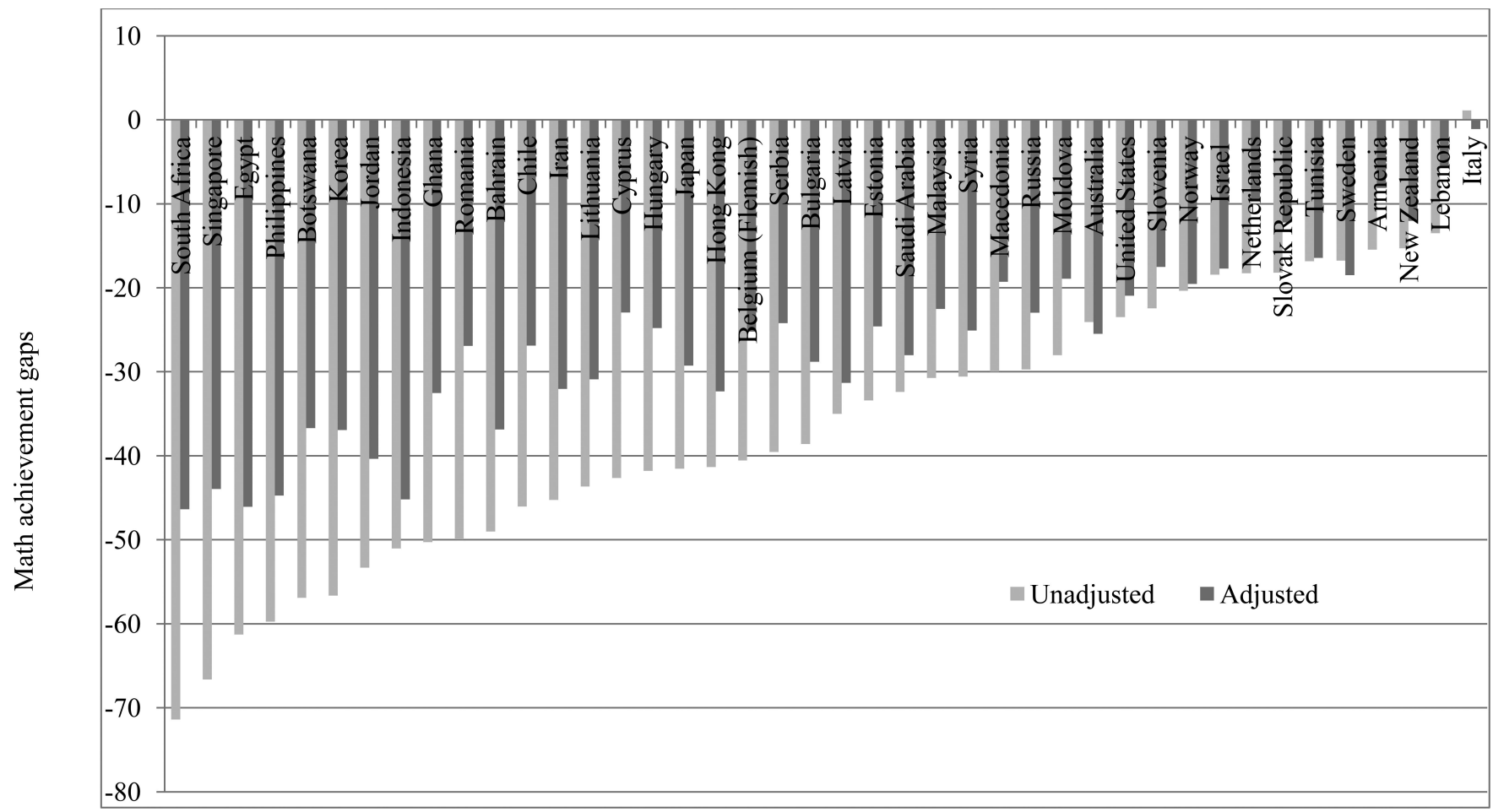

Figure 2.

Cross-National Variations in Unadjusted and Adjusted Differences in Math Achievement between Students Who Worked at a Paid Job after School and Students Who Did Not 


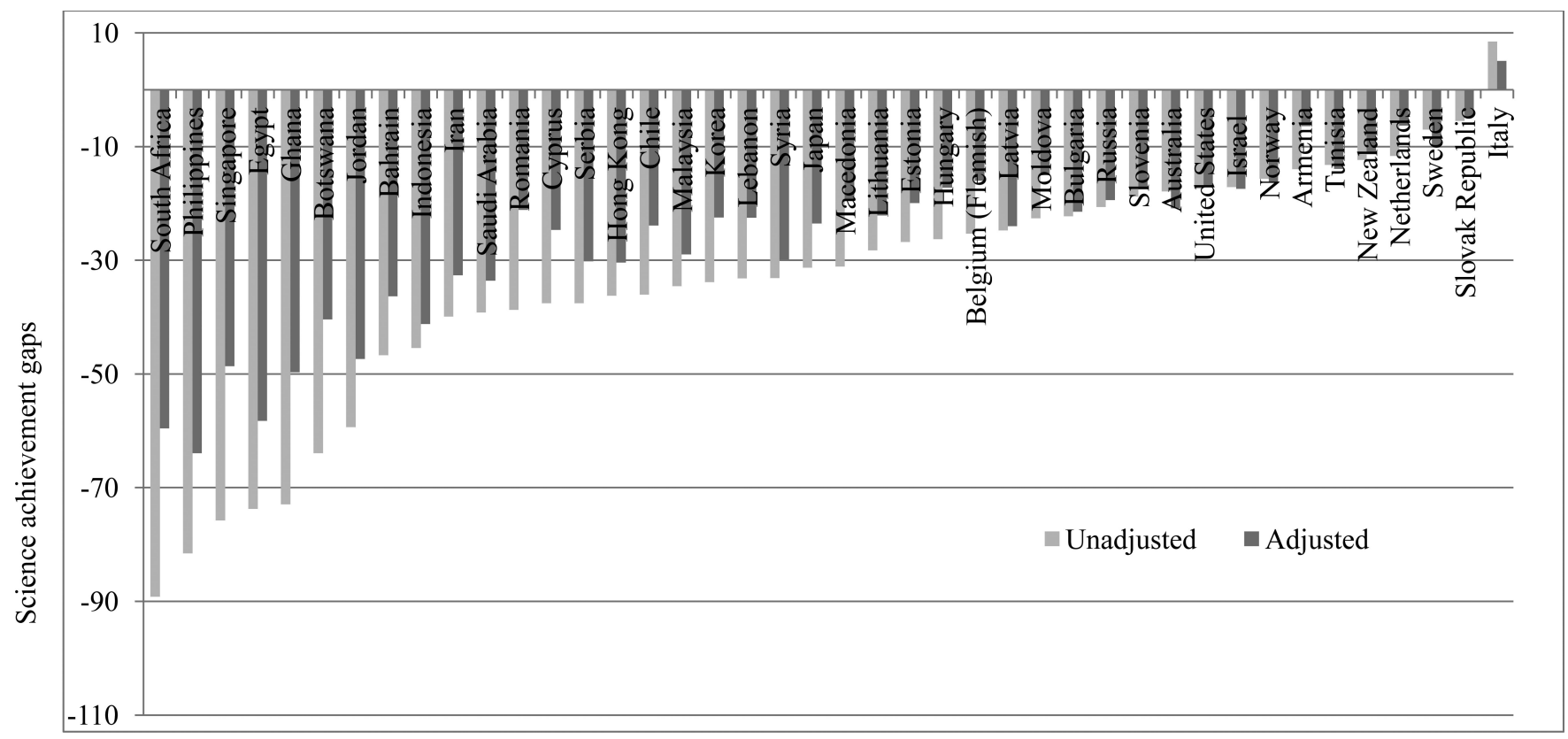

Figure 3.

Cross-National Variations in Unadjusted and Adjusted Differences in Science Achievement between Students Who Worked at a Paid Job after School and Students Who Did Not 
Table 1

Descriptive Statistics of Country-Level Variables Included in Analyses by Country

\begin{tabular}{|c|c|c|c|c|c|}
\hline Country & $\begin{array}{r}\text { GDP per capita }{ }^{a} \\
\text { (US dollars) }\end{array}$ & $\begin{array}{r}\text { Duration of } \\
\text { compulsory }\end{array}$ & 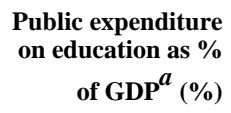 & ILO ratification $^{b}$ & $\begin{array}{r}\text { Prevalence of } \\
\text { student } \\
\text { employment }(\%)\end{array}$ \\
\hline Armenia & 3,070 & 8 & 2.1 & 0 & 47.8 \\
\hline Australia & 30,003 & 11 & 4.8 & 0 & 18.5 \\
\hline Bahrain & 25,987 & 9 & 3.4 & 0 & 31.9 \\
\hline Belgium (Flemish) & 30,281 & 13 & 6.0 & 1 & 10.4 \\
\hline Botswana & 10,326 & 10 & 9.5 & 0 & 27.2 \\
\hline Bulgaria & 8,209 & 8 & 4.1 & 1 & 11.8 \\
\hline Chile & 10,449 & 12 & 4.1 & 0 & 10.4 \\
\hline Cyprus & 21,795 & 9 & 7.3 & 0 & 23.5 \\
\hline Egypt & 4,033 & 8 & 4.9 & 0 & 32.3 \\
\hline Estonia & 13,395 & 9 & 5.3 & 0 & 23.5 \\
\hline Ghana & 1,067 & 10 & 5.4 & 0 & 41.6 \\
\hline Hong Kong & 29,261 & 9 & 4.3 & 1 & 6.8 \\
\hline Hungary & 15,342 & 10 & 5.9 & 0 & 10.9 \\
\hline Indonesia & 2,695 & 9 & 3.2 & 0 & 36.6 \\
\hline Iran & 8,093 & 5 & 4.8 & 0 & 25.6 \\
\hline Israel & 22,303 & 11 & 6.8 & 1 & 32.1 \\
\hline Italy & 27,138 & 9 & 4.7 & 1 & 70.5 \\
\hline Japan & 27,482 & 9 & 3.7 & 0 & 13.3 \\
\hline Jordan & 3,642 & 10 & 4.9 & 0 & 31.8 \\
\hline Korea, South & 20,181 & 9 & 4.4 & 0 & 3.9 \\
\hline Latvia & 10,618 & 9 & 5.3 & 0 & 24.9 \\
\hline Lebanon & 8,565 & 9 & 2.6 & 0 & 51.5 \\
\hline Lithuania & 12,028 & 9 & 5.2 & 0 & 14.2 \\
\hline Macedonia & 6,434 & 8 & 3.5 & 1 & 27.1 \\
\hline Malaysia & 10,060 & 6 & 7.5 & 0 & 12.1 \\
\hline Moldova & 1,916 & 9 & 5.4 & 0 & 24.3 \\
\hline Netherlands & 31,698 & 13 & 5.4 & 1 & 35.9 \\
\hline New Zealand & 23,542 & 12 & 6.6 & 0 & 29.0 \\
\hline Norway & 38,300 & 11 & 7.5 & 1 & 39.5 \\
\hline Philippines & 2,670 & 6 & 3.0 & 0 & 45.7 \\
\hline Romania & 7,678 & 8 & 3.4 & 1 & 21.2 \\
\hline Russia & 9,237 & 10 & 3.7 & 1 & 11.6 \\
\hline Saudi Arabia & 18,603 & 6 & 7.1 & 0 & 41.9 \\
\hline Serbia & 6,927 & 8 & 4.7 & 0 & 13.9 \\
\hline Singapore & 37,738 & 6 & 3.0 & 0 & 6.6 \\
\hline Slovak Republic & 13,598 & 9 & 4.3 & 1 & 24.9 \\
\hline Slovenia & 20,520 & 9 & 5.8 & 0 & 23.3 \\
\hline South Africa & 7,522 & 9 & 5.1 & 0 & 38.1 \\
\hline
\end{tabular}




\begin{tabular}{|c|c|c|c|c|c|}
\hline Country & $\begin{array}{r}\text { GDP per capita }{ }^{a} \\
\text { (US dollars) }\end{array}$ & $\begin{array}{r}\text { Duration of } \\
\text { compulsory } \\
\text { education }^{a} \text { (years) }\end{array}$ & 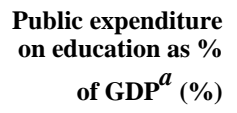 & ILO ratification $b$ & $\begin{array}{r}\text { Prevalence of } \\
\text { student } \\
\text { employment }(\%)\end{array}$ \\
\hline Sweden & 30,425 & 10 & 7.2 & 1 & 26.4 \\
\hline Syrian Arab Republic & 3,621 & 9 & 5.3 & 0 & 27.4 \\
\hline Tunisia & 6,251 & 11 & 6.8 & 1 & 29.1 \\
\hline United States & 38,196 & 12 & 5.8 & 0 & 24.8 \\
\hline Mean (SE) or Percentage & $15,735(1,738)$ & $9.2(0.3)$ & $5.1(0.2)$ & $31 \%$ & $27.1(.44)$ \\
\hline
\end{tabular}

${ }^{a}$ Data are drawn from UNESCO Institute for Statistics for the year of 2003. If information is unavailable in 2003, information available for adjacent years is used.

$b_{0}=$ not ratified, $1=$ ratified 
Table 2

Fixed Effects Estimates (Top) and Random Effects Estimates (Bottom) for Student Employment

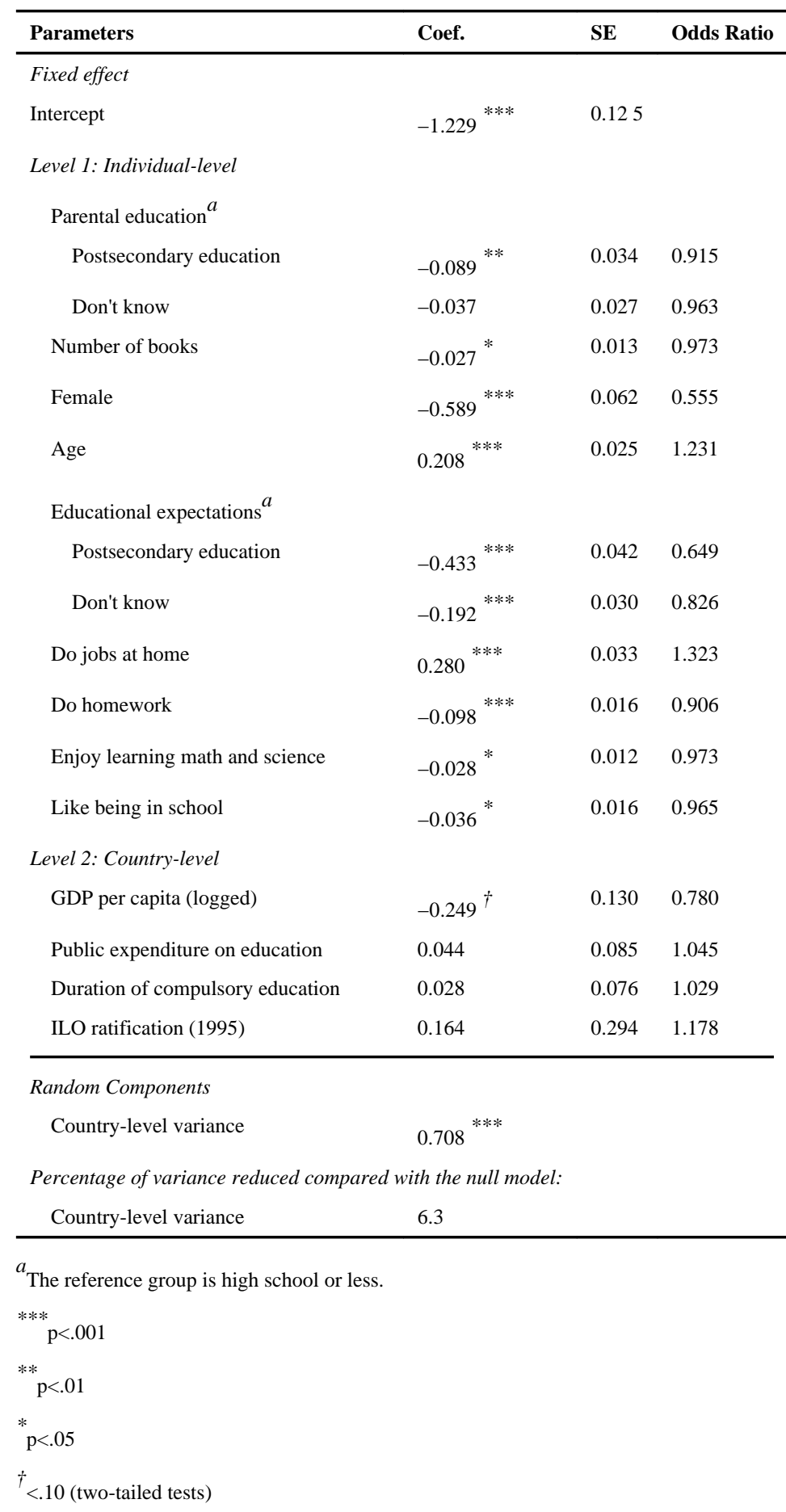


Table 3

Fixed Effects Estimates (Top) and Random Effects Estimates (Bottom) for Math and Science Achievement

\begin{tabular}{|c|c|c|c|c|}
\hline \multirow[b]{2}{*}{ Parameters } & \multicolumn{2}{|c|}{ Math } & \multicolumn{2}{|c|}{ Science } \\
\hline & Coef. & SE & Coef. & SE \\
\hline \multicolumn{5}{|l|}{ Fixed effect } \\
\hline Intercept & $474.575^{* * *}$ & 6.7643 & $481.993^{* * *}$ & 6.547 \\
\hline \multicolumn{5}{|l|}{ Level 1: Individual level } \\
\hline Student employment & $-24.605^{* * *}$ & 1.5583 & $-24.519^{* * *}$ & 2.058 \\
\hline \multicolumn{5}{|l|}{ Parental education $^{a}$} \\
\hline Postsecondary education & $16.797^{* * *}$ & 1.596 & $14.505^{* * *}$ & 1.547 \\
\hline Don't know & $-8.505^{* * *}$ & 1.6932 & $-11.165^{* * *}$ & 1.730 \\
\hline Number of books & $10.985^{* * *}$ & 0.7771 & $11.369^{* * *}$ & 0.922 \\
\hline Female & $-6.293^{* * *}$ & 1.4506 & $-15.099^{* * *}$ & 1.856 \\
\hline Age & $-12.714^{* * *}$ & 1.2143 & $-12.150^{* * *}$ & 1.590 \\
\hline \multicolumn{5}{|l|}{ Educational expectations ${ }^{a}$} \\
\hline Postsecondary education & $38.465^{* * *}$ & 1.997 & $35.287^{* * *}$ & 2.227 \\
\hline Don't know & $10.447^{* * *}$ & 1.7084 & $6.342^{* *}$ & 1.964 \\
\hline Do jobs at home & $-5.819^{* * *}$ & 0.9249 & $-3.396^{* * *}$ & 0.883 \\
\hline Do homework & $2.468^{* *}$ & 0.7244 & $3.104^{* *}$ & 0.810 \\
\hline Enjoy learning math or science & $12.123^{* * *}$ & 0.8946 & $3.272^{* * *}$ & 0.725 \\
\hline Like being in school & $-4.083^{* * *}$ & 0.8354 & $-2.067 *$ & 0.937 \\
\hline \multicolumn{5}{|l|}{ Level 2: Country level } \\
\hline \multicolumn{5}{|l|}{ Effects on the intercept } \\
\hline GDP per capita (logged) & $41.588^{* * *}$ & 10.024 & $41.673^{* * *}$ & 10.182 \\
\hline Duration of compulsory education & 2.343 & 4.7919 & 0.680 & 3.683 \\
\hline Public expenditure on education & $-13.851 *$ & 5.081 & $-9.050^{\dagger}$ & 4.674 \\
\hline ILO ratification (1995) & 14.781 & 12.836 & 9.933 & 11.766 \\
\hline Prevalence of student employment & $-2.233^{* *}$ & 0.5893 & $-1.931^{* *}$ & 0.510 \\
\hline \multicolumn{5}{|c|}{ Effects on the slope of student employment } \\
\hline GDP per capita (logged) & 2.496 & 1.951 & 5.438 & 3.421 \\
\hline Duration of compulsory education & 1.143 & 0.791 & $2.102^{\dagger}$ & 1.079 \\
\hline Public expenditure on education & -0.038 & 1.237 & -0.634 & 1.498 \\
\hline ILO ratification (1995) & $6.617^{*}$ & 2.751 & $10.345^{* *}$ & 3.571 \\
\hline Prevalence of student employment & $0.378^{* *}$ & 0.110 & 0.077 & 0.171 \\
\hline
\end{tabular}

Random Components 


\begin{tabular}{lccccc}
\hline & \multicolumn{2}{c}{ Math } & & \multicolumn{2}{c}{ Science } \\
\cline { 2 - 3 } \cline { 5 - 5 } Parameters & Coef. & SE & & Coef. & SE \\
\hline Country-level variance & $2250.2^{* * *}$ & & $2134.1^{* * *}$ \\
Individual-level variance & 4765.3 & & 5071.6 \\
Variance for the slope of student employment & $103.3^{* * *}$ & & \multirow{2}{*}{$217.6{ }^{* * *}$} \\
Percentage of variance reduced compared with the & null model: & & \\
Country-level variance & 0.48 & & 0.44 \\
Individual-level variance & 0.19 & & 0.15 \\
Variance for the slope of student employment & 0.57 & & 0.44 \\
\hline
\end{tabular}

${ }^{a}$ The reference group is high school or less.

***

$\mathrm{p}<.001$

** $\mathrm{p}<.01$

* $<<.05$

${ }^{\dagger}<.10$ (two-tailed tests) 